Review Article

\title{
Response and tolerance mechanism of food crops under high temperature stress: a review
}

\author{
Mecanismo de resposta e tolerância de culturas alimentares sob estresse de alta \\ temperatura: uma revisão
}

\author{
S. Han ${ }^{\mathrm{a}}$ (D), S. Jiangb*, R. Xionga, K. Shafiquec, K. R. Zahid ${ }^{\mathrm{d}}$ and Y. Wanga* (D) \\ aLiupanshui Normal University, School of Biological Sciences and Technology, Liupanshui, China \\ 'ZZhengzhou Normal University, Bioengineering Research Center, Zhengzhou, Henan, P.R. China \\ 'Government Sadiq College Women University, Department of Botany, Bahawalpur, Pakistan \\ dShenzhen University, Carson International Cancer Center, College of Life Sciences and Oceanography, Shenzhen Key Laboratory of Microbial \\ Genetic Engineering, Shenzhen, Guangdong, China
}

\begin{abstract}
High temperature stress events are critical factors inhibiting crop yield. Meanwhile, world population is growing very rapidly and will be reached up to 9 billion by 2050. To feed increasing world population, it is challenging task to increase about 70\% global food productions. Food crops have significant contribution toward global food demand and food security. However, consequences from increasing heat stress events are demolishing their abilities to survive and sustain yield when subjected to extreme high temperature stress. Therefore, there is dire need to better understand response and tolerance mechanism of food crops following exposure to heat stress. Here, we aimed to provide recent update on impact of high temperature stress on crop yield of food crops, pollination, pollinators, and novel strategies for improving tolerance of food crop under high temperature stress. Importantly, development of heat-resistant transgenic food crops can grant food security through transformation of superior genes into current germplasm, which are associated with various signaling pathways as well as epigenetic regulation in response to extreme high temperature stress.
\end{abstract}

Keywords: high temperature stress, food security, chromatin remodeling, epigenetic, pollen infertility.

\begin{abstract}
Resumo
Eventos de estresse de alta temperatura são fatores críticos que inibem o rendimento das culturas. Enquanto isso, a população mundial está crescendo muito rapidamente e atingirá até 9 bilhões em 2050. Para alimentar a crescente população mundial, é uma tarefa desafiadora aumentar cerca de 70\% da produção global de alimentos. As culturas alimentares têm uma contribuição significativa para a procura global de alimentos e a segurança alimentar. No entanto, as consequências do aumento de eventos de estresse por calor estão destruindo suas habilidades de sobreviver e manter a produção quando submetidos a estresse de alta temperatura. Portanto, há uma necessidade urgente de entender melhor o mecanismo de resposta e tolerância das safras de alimentos após a exposição ao estresse por calor. Aqui, nosso objetivo foi fornecer atualizações recentes sobre o impacto do estresse de alta temperatura no rendimento de culturas de alimentos, polinização, polinizadores e novas estratégias para melhorar a tolerância de culturas de alimentos sob estresse de alta temperatura. É importante ressaltar que o desenvolvimento de culturas alimentares transgênicas resistentes ao calor pode garantir segurança alimentar por meio da transformação de genes superiores em germoplasma atual, que estão associados a várias vias de sinalização, bem como à regulação epigenética em resposta ao estresse de alta temperatura extrema.
\end{abstract}

Palavras-chave: estresse de alta temperatura, comida segura, remodelação da cromatina, epigenética, infertilidade de pólen.

\section{Introduction}

Rapid climatic changes have increased the magnitude of extreme weather such as precipitation, high temperatures, and drought stress in agricultural regions (Boyer et al., 2013; Lesk et al., 2016). Planet's climate became warm by about $0.6{ }^{\circ} \mathrm{C}$ during 1910 and 1945 and it has become warmer from 1976 onwards as compared to previous 1000 years (Pachauri et al., 2014). According to the IPCC $5^{\text {th }}$ assessment report global average temperature was increased $0.85{ }^{\circ} \mathrm{C}$ from 1880-2012 (Pachauri and Meyer, 2014). Recently, the IPCC has anticipated that average

*e-mail: 1211817475@qq.com; 76759258@qq.com

Received: April 4, 2021 - Accepted: November 23, 2021

This is an Open Access article distributed under the terms of the Creative Commons Attribution License, which permits unrestricted use, distribution, and reproduction in any medium, provided the original work is properly cited. 
global temperature will be increased up to $3-6{ }^{\circ} \mathrm{C}$ by 2100 (Masson-Delmotte et al., 2018). Recent evidences show that increased climate impacts is because of anthropogenic emission of carbon dioxide and leads to global warming (IPCC, 2013; King et al., 2015).

It has been projected that world population will be exceed above 9 billion by 2050. In order to feed the 9 billion population, about $70 \%$ increment in global food production is required (Stratonovitch and Semenov, 2015). Extreme temperature will affect the goal of the target of achieving of $70 \%$ global food production for the 9 billion of world population by 2050. Growing evidences show that climate changes have caused significant crop yield losses and also damaged to food security. Various abiotic stresses including high temperature stress and drought have reduced productivity of various field crops over the years (Boyer et al., 2013). Climate changes have also damaged to food production in poor countries (Oseni and Masarirambi, 2011). There is no doubt that agricultural production has been continuously affected owing to climate changes and the average yield of field crops will depend on the regional differences in both the natural and anthropogenic factors that control crops responses (Rustad, 2008; Wei et al., 2014).

Above 200,000 plant species are present on the earth, among them approximately 80,000 plants species are edible to humans. In spite of wide range of plant species, about 95\% protein intake and calories of livestock and human have been obtained from only 20 to 25 plant species (Fuleky, 2009). Among major cereal crops, rice, maize, and wheat play central role in food demand across the globe (Hussain et al., 2019; Impa et al., 2021; Tack et al., 2015). However, climate changes have caused yield losses of these three plants species such as wheat, rice, and maize which supply $70 \%$ of total grain production worldwide (Iizumi et al., 2013; Liu et al., 2016a; Lobell et al., 2014). Nearly, 820 million population (or $11 \%$ of the current global population) are undernourished in terms of food intake, and 1.3 billion people are suffering from micronutrient deficiencies (WHO, 2019). Most of them are living in SubSaharan Africa and Asia. However, increment of $3{ }^{\circ} \mathrm{C}$ to $4{ }^{\circ} \mathrm{C}$ temperatures causes 15 to $35 \%$ crop yield losses in Asia and Africa whereas 25-35\% in Middle East (Ortiz et al., 2008). There are several review articles which raised general question of how to meet food demand of rising world population in future (Grote, 2014; Le Mouël and Forslund, 2017). Nevertheless, only few articles have been devoted to key role of staple food crops including maize and wheat (Shiferaw et al., 2013; Tadesse et al., 2019). Here, we aimed to provide recent update on impact of high temperature stress on crop yield of food crops, pollination, pollinators, and novel strategies for improving tolerance of food crop under high temperature stress.

\section{Review Writing Strategy}

To recapitulate and compile the desired literature related to response and tolerance mechanism of food crops, we conducted a literature search by using PubMed, Google, ScienceDirect, and Google Scholar Databases. Moreover, other information was also searched from reliable sources such as IPCC. Keywords used for literature search included High temperature stress, Food Security, pollination, pollinators, transcriptional factors, noncoding RNAs, Phytohormones, reactive oxygen species, heat shock proteins, chromatin remodeling, epigenetic, synthetic biology, and genome editing.

\section{Climate Change Limits Crop Yield}

Each year, extreme abiotic stress conditions including heat and drought affect crops productivity across the globe (Devireddy et al., 2021). The effects of these stresses are becoming alarming recent years and pose serious threat for food security across the globe (Degife et al., 2021; Raza et al., 2019). It has been predicted that we should increase crop yield about $25-70 \%$ by 2050 without putting pressure on the ecosystem functioning (Hunter et al., 2017; Wang et al., 2019). The largest decline in yields of cereal crops, including rice and wheat has also been observed in South Asia. If current rate of warming remains unchanged, wheat yield will be decreased nearly $50 \%$ by 2050 . Nearly, $60 \%$ decline will be in India and Bangladesh followed by Pakistan at $27 \%$. Rice yield will be decreased $40 \%$ in India, followed by Bhutan at $4 \%$, Bangladesh at $10 \%$, and Nepal at $32 \%$. Additionally, yield of sugarcane and maize will also reduced because of global warming. This is disquieting situation for the South Asia and global community. South Asia is not only second leading producer of wheat and rice across the globe, after China, but also the largest consumer of cereal crops. However, India is the second largest and Pakistan the eight largest countries growing wheat worldwide, India and Pakistan are the second largest and fifth largest consumer of wheat. Likewise, India has been reported second largest and Bangladesh the fourth largest rice consuming countries across the globe. Therefore, declining only rice and wheat production in South Asia can, thus, destabilize the world food market and will pose serious threat to global food security (Rasul, 2021).

Given importance to agriculture sector-based economies of these countries, this also reveals that South Asia will experience massive economic losses due to extreme climatic changes. A decline in crops productivity due to extreme heat and drought stress is also a serious threat for agriculture sector (Zandalinas et al., 2018). Importantly, high temperature stress during reproductive stage causes huge loss of crop yield. High temperature stress during pre-anthesis mediates floret infertility which translates to decline seed number (Bheemanahalli et al., 2019; Kumar et al., 2017a). This consequence can't be rescued and might result in an irreversible loss of crop productivity (Liu et al., 2019). Furthermore, a recent study suggests that only drought causes nearly $75 \%$ reduction of all the globally harvested areas of wheat, soybeans, rice, and maize, between 1983-2009 (Kim et al., 2019). In next section, we will discuss effect of high temperature stress on plants pollination because crop productivity is strongly linked with successful pollination.

\subsection{Effect of high temperature stress on plants pollination}

Plants are sessile and unable to face harsh effects of high temperature exposure that are increasing in period and rate duration because of recent climate change 
conditions. Although heat wave affects all the plants' growth stages, while plants' reproductive stages remain the most susceptible stages of the life cycle. This susceptibility during reproductive stage contributes to huge reduction in both the seed set and crops production (Hein et al., 2021; Jagadish et al., 2021). It has been reported that reproductive stage of various food crops including soybean (Zhao et al., 2017a), wheat (Liu et al., 2016b), maize (Liu et al., 2020), rice (Zhang et al., 2018) and cotton (Masoomi-Aladizgeh et al., 2021 ) is extremely sensitive to heat stress (Figure 1). Extreme high temperature stress leads to pollen abortion, thereby leading to failed pollination (Lohani et al., 2020a, b). Successful reproduction mainly relies on the interaction between pollen and pistil and as well as viability of the pistil and pollen following extreme heat stress. Both the pollen and pistil are very sensitive to high temperature stress (Masoomi-Aladizgeh et al., 2020; Wang et al., 2021b), however, available studies mainly focus on impact of heat wave on the pollen development. Nonetheless, recent data focuses on the sensitivity of female reproductive organ to heat stress in various crops such as wheat, maize, rice, sorghum, and tomato (Gonzalo et al., 2020; Jagadish, 2020; Lohani et al., 2020b). These novel findings demonstrate a substantial variation in response of pistil against high temperature stress across various crops. The pistil is comprised of stigma, style, and ovary. Both stigma and style are engaged in triggering, promoting, and guiding pollen tube growth toward female gametes within ovule. High temperature stress disrupts interaction between pollen and pistil and fertilization, thereby leading to reduction in both seed set and crop yield. High temperature stress during pollen tetrad and binucleate stages results in severe pollen damage despite of elevated sugar level, suggesting molecular mechanisms beyond carbohydrate supply as major for the pollen sterility (Masoomi-Aladizgeh et al., 2021). Further, high temperature stress during the development of pollen tube shows downregulation of

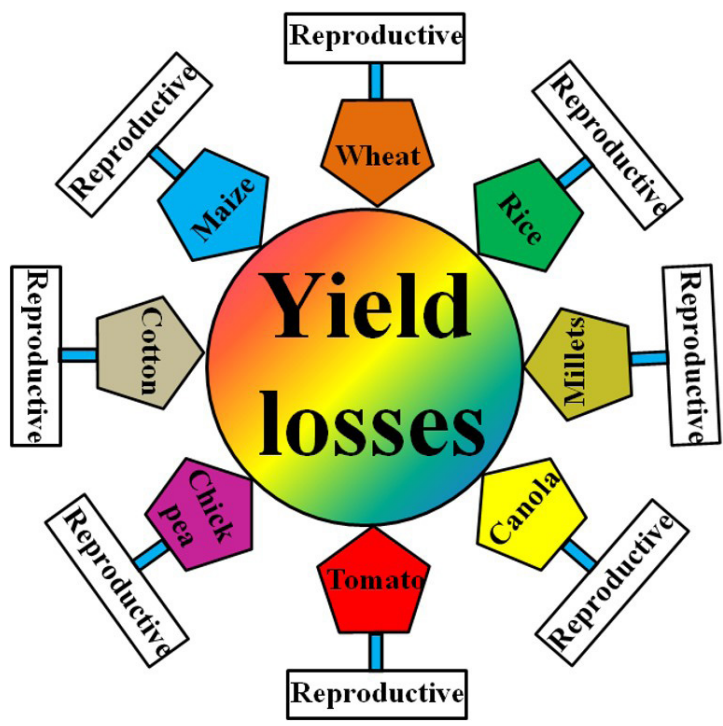

Figure 1. Schematic representation of most sensitive phase of various crops during high temperature stress. membrane transporters (Poidevin et al., 2020). Besides membrane transporters, existence of ribosomes on the noncoding RNAs has been proposed a key regulatory aspect of plants fertilization, which points out function of alternative players in both the pollen development and tube growth, apart from sugars (Masoomi-Aladizgeh et al., 2021; Poidevin et al., 2020). Even though sugar furnish is not major mechanism contributing to sterility of pollen grains in cotton (Masoomi-Aladizgeh et al., 2021), however, beans (Santiago et al., 2021) and several other plant species depend on the availability of sugar to sustain viability of pollen grains (Ferguson et al., 2021).

\subsection{Impact of high temperature stress on population of pollinators}

In this section, we will discuss about effect of high temperature stress on population of pollinators because successful plants pollination depend on the population of the pollinators.

Wild and managed pollinators provide huge benefits to society through contributing to food demand. Currently, climatic changes have been proved a serious threat to pollinators. A well-documented decline has been observed in both the wild and managed pollinators in various regions across the globe (Potts et al., 2016a). Accumulating evidences suggest that climate change extremely affects food production of the flowering crop species through reducing population of the pollinating insects and disturbing their regional distributions (Abrol, 2012; Hegland et al., 2009; Memmott et al., 2007; Potts et al., 2016b). Global warming affects flowering time of plants and causes plant communities to migrate poleward, and this shifting results in mismatches between mutualistic plants-pollinators pairs (Parmesan and Yohe, 2003), thereby disrupting interaction and functionality of the ecosystem. In addition, reduced overlap between plants flowering time and pollinator emergence reduces diet breadth for pollinators, thereby resulting in reduction of pollinators' population and enhanced death of both pollinators and plants.

Finally, elevated $\mathrm{CO}_{2}$ level also changes nutritional worth of major forages for pollinator species, indecisive outcomes for health of pollinators. Since 1842, one-third reduction has been found in goldenrod pollen protein content, the late-blooming plants that play key nutritional role for the overwintering of pollinators (Ziska et al., 2016). Chamberbased experiments show additional pollinators declines with enhanced atmospheric $\mathrm{CO}_{2}$ levels (Ziska et al., 2016). A modeling-based study has shown that global declines in pollinators will increase child birth defects and mortality from increased folate and vitamin A deficiency, respectively, and also enhance risk of diabetes, stroke, heart disease, and tumors in adults due to decreased dietary intake vegetables, fruits, seeds, and nuts (Smith et al., 2015).

\subsection{Tolerance mechanism of plants during heat stress}

To cope with extreme high temperature stress, plants have evolved various and interconnected signaling pathways such as, transcriptional factors (TFs), microRNAs (miRNAs), long noncoding RNAs (IncRNAs) phytohormones, 
reactive oxygen species (ROS), heat shock proteins (HSPsY and epigenetics etc, resulting in diverse response so as to confer heat tolerance (Figure 2).

\subsection{Role of transcriptional factors in response to high temperature stress}

Since last decade, huge success has been made in exploring potential role of transcriptional factors (TFs) in response to environmental stresses in various cereal crops. Transcriptional factors (TFs) play critical roles at transcriptional levels either activating or suppressing genes during high temperature stress. Nearly 7\% coding knack of the vascular plants genome is associated with transcriptional factors for regulating target genes at transcriptional level (Rushton et al., 2008). To date, scientists have identified thousands of TFs in plants, however, major TF families (AP2/ERF, HSFs, MYB, WRKY, NAC, etc), mediated through signal transduction pathways, recently been utilized to cope with heat stress in various food crops (Guo et al., 2020; Li et al., 2021; Xiang et al., 2021).

In wheat, TaWRKY008, TaWRKY122, and WRKY45 are engaged in drought and high temperature stress responses (Gupta et al., 2019). In wheat, overexpression of TaWRKY2 increases grain yield and drought tolerance. Overexpression of Arabidopsis based AtWRKY2 in transgenic wheat has resulted in increase of relative water content, soluble sugar, and activities of antioxidant enzymes to improve drought stress (Baillo et al., 2019; Wang et al., 2021a). In addition, six MYB TFs associated with high temperature stress have also been identified out of TaMYB80 is more effective during high temperature stress in transgenic Arabidopsis (Zhao et al., 2017b). In rice, overexpression of OsMYB1 gene has been proved effective in enhancing tolerance against high temperature stress (Deeba et al., 2017). In maize, OsMYB55 enhances tolerance against heat stress (Casaretto et al., 2016).

Recently, many novel and smart breeding approaches such as genome editing have been used to develop climate resilient crops by utilizing right TFs. For instance, AtMYB14 and AtMYB15 negatively regulate abiotic stress tolerance in Arabidopsis. This shows that both the AtMYB14 and AtMYB15 participate in the activation of those genes that induce sensitivity in plants against abiotic stress conditions. Hence, if we can manipulate these TFs then they couldn't regulate their respective genes

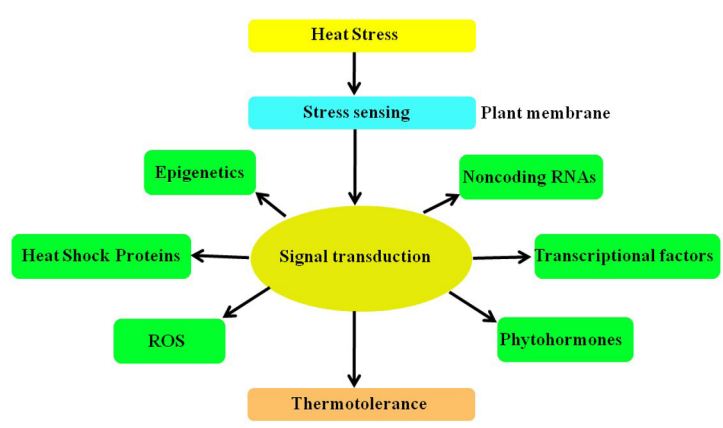

Figure 2. Schematic representation of tolerance mechanism of plants during heat stress. associated with sensitivity. Finally, plants can develop tolerance against specific abiotic stress because TF which was associated with proliferation of abiotic stress has been manipulated now. Similarly, we can found similar proteins in crop species using system biology and can be targeted via genome editing approach to manipulate their negative function in food crops.

\subsection{Role of miRNAs in plants during heat stress}

MicroRNAs (miRNAs) are about 20-24 nucleotide long noncoding endogenous regulatory RNAs that regulate expression and accumulation of target mRNAs. They are capable of modulating stress response (Zhao et al., 2016) and regulatory pathways (Curaba et al., 2014). Various evidences have been collected from miRNA-based studies in both cereal and major crops, including wheat, maize, rice, sorghum, cotton, and sunflower during abiotic stress conditions, thereby suggesting their potential role in regulating stress response in different plant species (Basso et al., 2019; Sun et al., 2019; Zhang, 2015). Under extreme heat stress, plants miRNAs have potential of improving its heat tolerance by regulating growth transition, flowering time, and floral organ development (Zhao et al., 2016). For instance, miRNA-156/157 has been emerged as a critical regulator of both flower development and male fertility during high temperature stress (Liu et al., 2017b; Wang et al., 2016; Xing et al., 2010).

In tomato, nearly 69 miRNAs have been reported in small RNA libraries of the stamen following high temperature stress (Pan et al., 2017). In rice, 8 target genes were corresponded to 26 heat-responsive miRNAs from panicle of heat-sensitive and heat-tolerant varieties through integrated sRNA sequencing with QTL mapping. Functional studies demonstrated that miR169r-5p was associated with heat tolerance in rice during flowering stage (Liu et al., 2017b). In cotton, 28 differentially expressed miRNAs have been identified from anthers of heat-sensitive and heat-tolerant varieties under heat stress (Chen et al., 2020; Ding et al., 2017). In cotton, miRNA-157 and miRNA-160 regulate auxin signaling pathway when anther is subjected to high temperature stress, to rescue male fertility (Ding et al., 2017).

To gain insights into identifying targeted miRNAs involved in stress response, we should confirm whether miRNAs abundance is changed during high temperature stress. Pegler et al. (2019) performed RNA-seq to identify miRNAs abundances in Arabidopsis following drought and heat stress. This novel approach have detected numerous miRNAs with elevated expression following drought and heat stress, hence identifying potential miRNAs that can be strong contenders for playing crucial roles under these stress conditions. This study provides a fundamental resource to identify stress-responsive miRNAs in major crops. In another study, López-Galiano et al. (2019) examined change in abundance of miR-159 in tomato under drought stress, where authors identified miR-159 was downregulated under stress, whereas mRNA level of its target gene was derepressed. These novel studies signify foundation of exploration of how miRNAs respond to different stresses and how they can 
be used in the development of heat stress tolerant crops. Given significance to central role of miRNAs in plants growth and development by targeting various regulatory genes, and their key role during stress response, their manipulation can alter agronomic traits. Zhang et al. (2019b) has provided overview on several gene silencing pathways and core apparatus in maize, and their roles in maize biology, describing the traits that miRNAs regulate and their use in controlling plant architecture, fertility, and heat stress response. This overview has disclosed the potential application of miRNAs in just maize. Based on deep knowledge on biology of plants miRNAs in the model crop species, future trail of this approach might be applied in major crops, while understanding their potential functions and applying this knowledge can improve various important traits in response to high temperature stress.

\subsection{Role of long noncoding RNAs in plants during heat stress}

Long noncoding RNAs (IncRNAs) are molecules of $>200$ nucleotide and lack discernible coding potential (Palazzo and Koonin, 2020; Rai et al., 2019). In plants, lncRNAs regulate different biological processes, including growth and development, sexual reproduction, and also drought and heat stress responses (Csorba et al., 2014; Liu et al., 2017a; Song et al., 2021). Long noncoding RNAs affect all the elements of the genes such as promoters, untranslated regions, introns, exons, and terminators, regulating gene expression at various levels such as transcription, chromatin remodeling, splicing and translation (Wierzbicki et al., 2021). A growing body of evidences suggests that lncRNAs can modulate drought responses through regulating stress-responsive genes transcription, chromatin remodeling, and antisense transcription-mediated modulation (Jha et al., 2020). Previously, genome-wide transcriptome analysis identified drought and heat stress-responsive IncRNAs in various food crops, including rice (Chung et al., 2016), maize (Pang et al., 2019; Zhang et al., 2014), soybean (Bhatia et al., 2020), wheat (Xin et al., 2011).

Moreover, IncRNAs regulate several drought-responsive regulatory genes participating in $\mathrm{ABA}$ and ethylene signaling, calcium signaling, and different metabolic processes in rice (Weidong et al., 2020). In recent years, key role of various abiotic stress-responsive genes and lncRNAs has been widely studied in plants. Huge efforts have been made in designing new bioinformatics tools for the identification of novel genes against abiotic stresses. A wide-ranging and better understanding of mode of actions of the lncRNAs, their diverse regulation patterns, unearthing of the target genes, and IncRNAs-mediated gene regulation is essential for food crops. We must focus on using advanced synthetic biology and genetic engineering tools to develop and effective approach for developing heat stress-tolerant food crops as well as other important crops.

\subsection{Role of phytohormones in response to high temperatures stress}

Phytohormones regulate different biological events occurred during plants' life cycle. A variety of phytohormones such as abscisic acid, jasmonic acid, salicylic acid, and ethylene play critical roles in plants growth and heat stress responses (Zhao et al., 2021a). Abscisic acid (ABA) has been reported as a key regulator of plants growth and development and also plants stress responses. Generally, ABA controls plants growth and development to coordinate plants adaption to high temperature stress (Suzuki et al., 2016). Moreover, ABA participates in the developmental process of anther and pollen (Dai et al., 2018; Kovaleva et al., 2018). In rice, exogenous ABA application prevents pollen sterility by mediating sugar metabolism under high temperature stress (Rezaul et al., 2019). Salicylic acid (SA) also plays central role in protecting plants against extreme heat stress. In tomato, SA prevents damage caused by high temperature stress and modulates activities of various antioxidant enzymes such as peroxidase (POD, superoxide dismutase (SOD), and catalase (CAT). In addition, exogenous application of SA increases tolerance of tomato plants against heat stress by enhancing photosynthesis efficiency and scavenging reactive oxygen species (ROS) by inducing antioxidants (Jahan et al., 2019). In rice, SA exogenous application reverses pollen abortion through scavenging of ROS under high temperature stress (Feng et al., 2018). In chickpea, SA and ABA exogenous application activate zeaxanthin pigment cycle prior to flowering, which showed positive response to different physiological processes such photosynthesis and related pigments, thereby leading to less high temperature susceptibility index (Kumar et al., 2020).

Cytokinin also plays crucial role in plants growth and development and also high temperature and drought stress responses (Cortleven et al., 2019; Pavlů et al., 2018). It has great potential for developing more resilient plants for high yields (Berka et al., 2020). Recently, novel transgenic barley lines have been developed by regulating cytokinin content for higher yield and enhanced drought resilience (Holubová et al., 2018; Ramireddy et al., 2018). We foresee that Phytohormones-related mechanisms should be explored in recent crop breeding programs against heat stress tolerance, both from a basic research and application outlook. Certainly, transgenic Phytohormonesmodifications are currently being implemented in various crop species due to their strong effect on high yield. A better understanding of the Phytohormones-mediated regulation of metabolic pathways and heat-responsive genes and identification of novel genes under Phytohormones treatment may improve essential knowledge of the plants hormonal biology, permitting both the selection and in planta characterization of novel regulators for plants heat stress adaption.

\subsection{Role of ROS signaling in plants heat stress response}

The hormonal and ROS signaling are snugly synchronized for regulating growth and development of the plants. In this section, we will discuss about ROS signaling in plants during heat stress conditions. Plants being sessile organisms have equipped with arsenal adaptive strategies to cope with harsh environmental conditions including high temperature stress (Bulgari et al., 2019; He et al., 2018). The key strategy includes induction of the systemic 
signals from an area under stress to an unstressed region that consequently activates defense or enhances resilience (Kumar et al., 2017b), arising from signal transducers, including Reactive Oxygen Species (ROS) (Tsaniklidis et al., 2020). The overproduction of ROS than scavenging abilities of antioxidants can result in an oxidative burst within plant cells (Mullineaux and Baker, 2010). For example, overproduction of ROS is accompanied with reduced ROS scavenging capacities of the antioxidants in the pistil of pearl millet as compared to pollen, and led to sensitivity of pistil to high temperature stress (Djanaguiraman et al., 2018). Besides oxidative damage, the critical role of ROS has been well documented during signal transduction that promotes tolerance against high temperature stress (Medina et al., 2021). ROS signaling arbitrates the transcription of various genes which are involved in plant growth and development, as well as protects plants against high temperature stress (Dvorak et al., 2020). ROS act as double-edge sword that stimulates oxidative stress in plants when their production surpasses threshold levels, but low concentration mediates signal transduction that assists retaining cellular homeostasis and improves plants acclimatization abiotic stress conditions. To keep balance between ROS production and their quenching, plants engage antioxidant machinery. However, their capacities diminish during extreme stress conditions. Devising tools that could prevent the damaging aspects of ROS by manipulating genes or signaling pathways involved in ROS overproduction during heat stress conditions improving plants' heat-tolerance mechanisms may unlock avenues for developing new generation high temperature stressresilient crops.

\subsection{Role of heat shock protein}

To survive under high temperature stress, plants need to sense a slight increment in temperature to launch an appropriate genetic program. To this end, heat shock proteins (HSPs) play critical role in sensing and initiating heat shock response in plants during high temperature stress. Heat shock response is triggered by HSPs which are accumulated swiftly under temperature increment to reduce expected damage (Serrano et al., 2019). Both the proteome and transcriptome-based studies reported HSPs-mediated regulatory response in plants during high temperature stress (Guihur et al., 2021; Zhao et al., 2021b). With serious concern about high temperature stress, many scientists have utilized HSPs to develop heat-tolerant crops (Chauhan et al., 2012; Song et al., 2014). When plants are exposed to high temperature stress as a result HSPs and heat shock transcription factors (HSFs) genes are induced. The HSFs swiftly induce HSPs, hence, both HSPs and HSFs play crucial role in inducing thermotolerance in plants during high temperature stress (Ohama et al., 2017; Ren et al., 2019). In rice, OsHSP18 plays a key role in improving tolerance against heat stress (Kuang et al., 2017). Similarly, HSP70, HSP90, and HSP100 are upregulated in barley following heat stress exposure during reproduction stage (Chaudhary et al., 2019). Moreover, GhHSP70-26 overexpression in tobacco, while GhHSP70-26 silencing in cotton improves tolerance against drought stress (Ni et al., 2021). Taken together, these evidences suggest that HSPs play important role in heat stress response and overexpression of novel HSPs in food crops can improve their resistance against heat and drought stress conditions.

\subsection{Epigenetic changes in plants to heat stress response}

Epigenetics is defined as changes in gene expression owing to DNA methylation and post-translational modifications to histones without changing DNA sequence (Agarwal et al., 2020).Transcriptomic activity of organisms is influenced by epigenetic regulation. Reprogramming by epigenetic changes triggered by several environmental challenges contributes to phenotypic diversity and defense against these challenges. Various environmental stresses are involved in changing genes expression levels by different mechanisms namely histone modification and DNA methylation. Since last two decades, epigenetics branch is continuously progressing. Improvement of crops by using traditional breeding approach is expensive, time consuming, tedious, and unable to meet progressive living standards and global demand, while epigenetics have shown great potential for improvement of crops with respect to nutritional quality and yield by creating novel epialleles (Saraswat et al., 2017). DNA is modified by methylation in response to environmental stresses. However, gene expression can be maintained by keeping balance of methylation and demethylation at the target promoters. Modification in this equilibrium affects stress response either positively (Dowen et al., 2012) or negatively (Lee et al., 2014). Environmental stresses induce chromatin remodeling, which controls gene transcription. It is necessary to understand how stress signals activate genes and changes in higher-order organization.

Accumulating evidences suggest that HDACs HD2C, HDA9, and HDA15 are implicated in temperature responses (Mayer et al., 2019; Park et al., 2019). HDA6 regulates various abiotic-stress-responsive genes (ABI1, ABI2, and ERF4) through communicating with HD2C (Luo et al., 2017), while HDA19 with SIN3, SAP18, ERF3, ERF4, and ERF7 are part of the chromatin remodeling complexes in abiotic stress responses. Molecular mechanism of the HDA9 function in signal transduction under abiotic stress responses remains unknown. Recently, a model has been suggested for better understanding key role of HDA9 in ABA-dependent drought stress signaling in plants (Baek et al., 2020). SRTs and HDA15 are played critical role in plants hormone signaling. The HDA15 regulates ABA-dependent signaling by interacting with MYB96. Under high ABA level, MYB96 induces transcription of the ABA-responsive genes, but requires HDA15 to inhibit transcription of ABA-suppressed RHO OF PLANTS genes by promoting $\mathrm{H} 3$ and $\mathrm{H} 4$ deacetylation at their promoters (Lee and Seo, 2019). Here, we recommend that epigenetics changes and chromatin remodeling are integral parts of plants signaling pathways during heat or drought stress that bridge gap between downstream gene regulation, transcriptional factors, and transcription machinery for signaling output. In addition, we should also decipher nature of plants signals that trigger target epigenetic 
modification, accurate mechanisms of how chromatin remodeling and gene regulation dictate responses to diverse signaling pathways, and specific routes by which abiotic stresses feed back to the epigenome landscapes.

\section{Novel Approaches for Developing Stress Tolerance Crops}

To warrant the fear of global food security in coming years and achieve target of "zero hunger" anticipated by the FAO, crops yield should be increased to meet the food demand of 9.7 billion people by 2050 . However, owing to extreme heat stress and other environmental factors responsible for climate change, agricultural production is significantly decreasing and counteracting objective of "zero hunger." Climate change contributes to various abiotic stresses, among which high temperature is considered critical yield-limiting factor across the globe. Extreme heat stress could disrupt metabolic homeostasis; hence, plants require wide modifications to cope with extreme stress conditions (Raza et al., 2021). To this end, biotechnological tools provide prodigious possibility to increase crops yield to feed worldwide population.

\subsection{Genome editing for heat stress resistance}

Now a days, genome editing has been emerged as an effective tool for improving crops tolerance mechanism either by gain of gene function, loss of gene function, or multiplex genome editing strategy (Sedeek et al., 2019). There is dire need to use genome editing technology to tackle detrimental climatic changes without affecting global food production. In this line, CRISPR technology may play a key role in food crops improvement. To date, three novel CRISPR systems (Cas9, Cas12a, and Cas12b) for the editing of plants genome have been effectively demonstrated (Ming et al., 2020; Zhang et al., 2019a). These novel tools can make CRISPR technology more effective not only for improving traditional plant breeding but also fundamental research (Chen et al., 2019; Pramanik et al., 2020; Veillet et al., 2020). Growing evidences suggest that CRISPR technology has been emerged as a promising genome editing tool for plants against high temperature stress (Li et al., 2019; Wang et al., 2017).

Recently, scientist have investigated the potential role of OsSAPK2 (osmotic stress/ABA activated protein kinase 2) by using loss-of-function mutants through CRISPR/ Cas. They have designed sgRNA to target third exon of gene. Their findings show that sapk2 mutants display an ABA-insensitive phenotype and show more sensitivity to drought stress than wild type, thereby suggesting that OsSAPK2 plays crucial role against drought stress in rice (Lou et al., 2017). In maize, CRISPR-Cas9 enhances expression level of ARGOS8 to develop drought tolerance; ARGOS8 promoter has been changed into GOS2. These mutants led to increased grain yield during drought stress (Shi et al., 2017). More recently, CRISPR-Cas9 approach has been applied to knockout RVE7 and 4CL genes in the protoplast of chickpeas to better understand molecular mechanism of drought stress. This study has been designed to conduct CRISPR-Cas9 for drought tolerance and propose effective method for use of free gene editing in the recalcitrant species (Badhan et al., 2021).

In cotton, CRISPR-Cas9 mediated pooled sgRNAs assembly has been optimized to target multiple genes associated with male sterility. Results show that pooled sgRNAs assembly provides a new road map for designing sgRNAs to target both the desired and multiple genes. CRISPR-Cas9 mediated pooled sgRNAs assembly not only applied in cotton, and also be used for all the plant species, particularly those have complex genomes. This study will rescue to cotton male sterility and also provide more genetic resources to improve several traits on field level (Ramadan et al., 2021). Taken together, CRISPR approach offers opportunity to modernized crops genome engineering for improving crops yield and resilience to climate change. In addition, we should take lession from the past experience and make new efforts to improve technology to avoid regulatory obstacles and make sure that its fruits are within reach for the poor and for survival of the farmers. Genome editing tools are poised to remodel agriculture and global food security to feed burgeoning population worldwide.

\subsection{Role of synthetic biology for developing resilient crops against high temperature stress}

In recent years, plant synthetic biology has been emerged as a key approach and provides a platform to combine plant biology with engineering principles (Kassaw et al., 2018). It has ability for developing drought tolerant transgenic (Borland et al., 2014; DePaoli et al., 2014; Llorente et al., 2018). Initially, it has been used for bacterial systems, but now also applied to plants. Synthetic regulatory systems have been proved promising tools for developing plant varieties with desired traits. For the development of sentinel plants demonstrating novel traits, effective genetic circuits must be goal of the designing team. Effective genetic circuits can be designed by using Bio-CAD for designing (Nielsen et al., 2016) and Cell Modeller (Dupuy et al., 2008) for assembling genetic parts. The orthogonal genetic components posses the capability to work independently of endogenous regulatory mechanisms of plants (Chen et al., 2013; Morey et al., 2012). Moreover, potential to manage activation of the genetic circuits can facilitate us switch on/off the desired traits as when needed.

In addition, incorporation of the regulatory components including terminators and insulators can also help in controlling synthetic genetic circuit (Y.-J. Chen et al., 2013). However, plants genetic functions are very complex and regulated a series of environmental cues such as temperature, light, and photoperiod, which in turn affect synthetic gene circuit control. These factors, along with gene regulatory information available from various omic studies, must be incorporated during development of sentinel plants. Plants biosensors have been designed for sensing 2,4,6-trinitrotolune (TNT) through two-component synthetic gene circuit (Antunes et al., 2011). First component serves as transmembrane signal activator following TNT exposure. Then it triggers second component via activation of synthetic promoter. The promoter controls genes activity 
which suppresses chlorophyll synthesis and induces its degradation. Lettuce and Arabidopsis have been modified to signal for bacterial contamination effectively through a gene circuit controlled by a positive autoregulatory transcriptional feedback loop (Czarnecka et al., 2012). This emerging approach has great potential to be used broadly, for developing sentinel plant that detects abiotic stresses including high temperature in field and activates gene regulation machinery for imparting heat stress tolerance.

\section{Future Perspectives for Application of Modern tools for Improving Crops Genetics}

Global elevations in climate have increased severity and unpredictability of extreme high temperature stress, threatening crop production sustainability and food security (Valliyodan et al., 2017). In order to produce an ideotype in terms of quantity, quality, and resistant is a challenging task in traditional breeding. Although utilizing novel biological tools, this task can't be achieved to meet the increased demand of global food. Conventional breeding in developed countries has been declined whereas in developing countries latest technology and strategies are lacking due to less funds. However, sharing information, germplasm resources and technology can helpful for solving several issues in developing countries (Zahid et al., 2016). Growing evidences show that reproductive phase is the most vulnerable stage to extreme heat stress in most of the crops. There is dire need to find out heatresistant germplasm for the tailored breeding, for better understanding of pollen development and fertilization and to illustrate reaction of reproductive tissues under high temperature stress (Grover et al., 2016). Various heat-tolerant plant species have been evolved via process of natural selection through attaining acclimation and adjustment mechanism. Wild species and exotic can grow in stressful conditions and possess stress-tolerant features as compared to cultivars (Mickelbart et al., 2015).

Introduction of heat-tolerant traits into the crop germplasm will enhance the diversity to improve crop production sustainability under extreme pattern of climatic change. To achieve this task, we have to discover heatresistant genetic resources and then incorporate them into the elite germplasm (Foyer et al., 2016). Utilization of natural variation might be a cornerstone approach in plant breeding to increase performance of field crops. There is need to identify stress-tolerance genes for multiple signaling pathways such transcriptional factors signaling, calcium signaling, Sugar signaling, hormone signaling, gene expression signaling, noncoding RNAs and epigenetic regulation from natural genetic variation sources and transformed into current germplasm (Figure 3). Recently, dCas and CRISPR/Cas9 technologies have provided new roadmap in epigenetic field. These novel tools can enable manipulation of the desired epigenetic traits and can be used to modify various crops phenotypes or to investigate relationship between epigenome and transcriptional control under extreme heat stress (Moradpour and Abdulah, 2020). In addition, stress-tolerant genes can be discovered by conducting genome-wide association studies (GWAS)

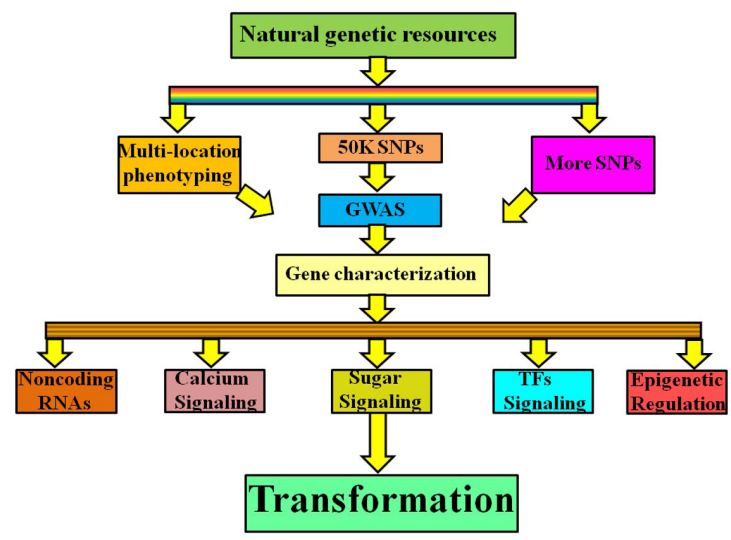

Figure 3. Process of development of heat-resistant cultivars. Identify heat-resistant genes from natural genetic resources through genome wide association mapping and then study the study how these genes are operated. Select those genes which are associated with various signaling pathways and then transform them into current germplasm.

(Varshney et al., 2016). Among stress-tolerant genes, we should identify pioneer transcriptional factors which possess the ability of directly binding to nucleosomes of the closed chromatin and play critical role in the opening of closed chromatin through depositing active histone modification mark. More recent study has shown that active marks and repressive marks coordinate with each other to build a novel chromatin landscape which supports coregulation of bidirectional gene pairs (Fang et al., 2010).

\section{Acknowledgements}

This work was supported in part by the Science and Technology Innovation Team Project of Liupanshui Normal University (Grant \# LPSSYKJTD201602), the Research Foundation for Advanced Talents of Liupanshui Normal University (Grant \# LPSSYKYJJ201601), and the Science and Technology Platform and Talent Team Project of Science and Technology Department of Guizhou Province (QKH * Platform |\& Talent [2018]5777), Young Science and Technology Talents Development Project of Guizhou Provincial Education Department (Grant Nos QIANJIAOHEZI*KY *[2018]371), Science and Technology project of Liupanshui City (Grant \#52020-2018-04-09).

\section{References}

ABROL, D.P., 2012. Climate change and pollinators. In: D.P. ABROL, ed. Pollination biology: biodiversity conservation and agricultural production. Dordrecht: Springer, pp. 479-508.

AGARWAL, G., KUDAPA, H., RAMALINGAM, A., CHOUDHARY, D., SINHA, P., GARG, V., SINGH, V.K., PATIL, G.B., PANDEY, M.K., NGUYEN, H.T., GUO, B., SUNKAR, R., NIEDERHUTH, C.E. and VARSHNEY, R.K., 2020. Epigenetics and epigenomics: underlying mechanisms, relevance, and implications in crop improvement. Functional \&'Integrative Genomics, vol. 20, no. 6, pp. 1-23. http:// dx.doi.org/10.1007/s10142-020-00756-7. PMid:33089419. 
ANTUNES, M.S., MOREY, K.J., SMITH, J.J., ALBRECHT, K.D., BOWEN, T.A., ZDUNEK, J.K., TROUPE, J.F., CUNEO, M.J., WEBB, C.T., HELLINGA, H.W. and MEDFORD, J.I., 2011. Programmable ligand detection system in plants through a synthetic signal transduction pathway. PLoS One, vol. 6, no. 1, pp. e16292. http:// dx.doi.org/10.1371/journal.pone.0016292. PMid:21283542.

BADHAN, S., BALL, A.S. and MANTRI, N., 2021. First report of CRISPR/ Cas9 mediated DNA-free editing of 4CL and RVE7 genes in chickpea protoplasts. International Journal of Molecular Sciences, vol. 22, no. 1, pp. 396. http://dx.doi.org/10.3390/ijms22010396. PMid:33401455.

BAEK, D., SHIN, G., KIM, M.C., SHEN, M., LEE, S.Y. and YUN, D.-J., 2020. Histone deacetylase HDA9 with ABI4 contributes to abscisic acid homeostasis in drought stress response. Frontiers in Plant Science, vol. 11, pp. 143. http://dx.doi.org/10.3389/ fpls.2020.00143. PMid:32158458.

BAILLO, E.H., KIMOTHO, R.N., ZHANG, Z. and XU, P., 2019. Transcription factors associated with abiotic and biotic stress tolerance and their potential for crops improvement. Genes, vol. 10, no. 10, pp. 771. http://dx.doi.org/10.3390/genes10100771. PMid:31575043.

BASSO, M.F., FERREIRA, P.C.G., KOBAYASHI, A.K., HARMON, F.G., NEPOMUCENO, A.L., MOLINARI, H.B.C. and GROSSI-DE-SA, M.F., 2019. Micro RNA s and new biotechnological tools for its modulation and improving stress tolerance in plants. Plant Biotechnology Journal, vol. 17, no. 8, pp. 1482-1500. http:// dx.doi.org/10.1111/pbi.13116. PMid:30947398.

BERKA, M., LUKLOVÁ, M., DUFKOVÁ, H., BERKOVÁ, V., NOVÁK, J. SAIZ-FERNÁNDEZ, I., RASHOTTE, A.M., BRZOBOHATÝ, B. and ČERNÝ, M., 2020. Barley root proteome and metabolome in response to cytokinin and abiotic stimuli. Frontiers in Plant Science, vol. 11, pp. 590337. http://dx.doi.org/10.3389/ fpls.2020.590337. PMid:33250914.

BHATIA, G., SINGH, A., VERMA, D., SHARMA, S. and SINGH, K., 2020. Genome-wide investigation of regulatory roles of IncRNAs in response to heat and drought stress in Brassica juncea (Indian mustard). Environmental and Experimental Botany, vol. 171, pp. 103922. http://dx.doi.org/10.1016/j.envexpbot.2019.103922.

BHEEMANAHALLI, R., SUNOJ, V.S.J., SARIPALLI, G., PRASAD, P.V.V., BALYAN, H.S., GUPTA, P.K., GRANT, N., GILL, K.S. and JAGADISH, S.V.K., 2019. Quantifying the impact of heat stress on pollen germination, seed set, and grain filling in spring wheat. Crop Science, vol. 59, no. 2, pp. 684-696. http://dx.doi.org/10.2135/ cropsci2018.05.0292.

BORLAND, A.M., HARTWELL, J., WESTON, D.J., SCHLAUCH, K.A., TSCHAPLINSKI, T.J., TUSKAN, G.A., YANG, X. and CUSHMAN, J.C., 2014. Engineering crassulacean acid metabolism to improve water-use efficiency. Trends in Plant Science, vol. 19, no. 5, pp. 327-338. http://dx.doi.org/10.1016/j.tplants.2014.01.006. PMid:24559590.

BOYER, J.S., BYRNE, P., CASSMAN, K.G., COOPER, M., DELMER, D., GREENE, T., GRUIS, F., HABBEN, J., HAUSMANN, N., KENNY, N., LAFITTE, R., PASZKIEWICZ, S., PORTER, D., SCHLEGEL, A., SCHUSSLER, J., SETTER, T., SHANAHAN, J., SHARP, R.E., VYN, T.J., WARNER, D. and GAFFNEY, J., 2013. The US drought of 2012 in perspective: a call to action. Global Food Security, vol. 2, no. 3, pp. 139-143. http://dx.doi.org/10.1016/j.gfs.2013.08.002.

BULGARI, R., FRANZONI, G. and FERRANTE, A., 2019. Biostimulants application in horticultural crops under abiotic stress conditions. Agronomy, vol. 9, no. 6, pp. 306. http://dx.doi.org/10.3390/ agronomy9060306.

CASARETTO, J.A., EL-KEREAMY, A., ZENG, B., STIEGELMEYER, S.M., CHEN, X., BI, Y.-M. and ROTHSTEIN, S.J., 2016. Expression of OsMYB55 in maize activates stress-responsive genes and enhances heat and drought tolerance. BMC Genomics, vol. 17, no. 1, pp. 312. http://dx.doi.org/10.1186/s12864-016-2659-5. PMid:27129581.

CHAUDHARY, R., BARANWAL, V.K., KUMAR, R., SIRCAR, D. and CHAUHAN, H., 2019. Genome-wide identification and expression analysis of Hsp70, Hsp90, and Hsp100 heat shock protein genes in barley under stress conditions and reproductive development. Functional E' Integrative Genomics, vol. 19, no. 6, pp. 1007-1022. http://dx.doi.org/10.1007/s10142-019-00695-y. PMid:31359217.

CHAUHAN, H., KHURANA, N., NIJHAVAN, A., KHURANA, J.P. and KHURANA, P., 2012. The wheat chloroplastic small heat shock protein (sHSP26) is involved in seed maturation and germination and imparts tolerance to heat stress. Plant, Cell \&'Environment, vol. 35, no. 11, pp. 1912-1931. http://dx.doi.org/10.1111/j.13653040.2012.02525.x. PMid:22530593.

CHEN, J., PAN, A., HE, S., SU, P., YUAN, X., ZHU, S. and LIU, Z., 2020. Different microRNA families involved in regulating high temperature stress response during cotton (Gossypium hirsutum L.) anther development. International Journal of Molecular Sciences, vol. 21, no. 4, pp. 1280. http://dx.doi.org/10.3390/ ijms21041280. PMid:32074966.

CHEN, K., WANG, Y., ZHANG, R., ZHANG, H. and GAO, C., 2019. CRISPR/Cas genome editing and precision plant breeding in agriculture. Annual Review of Plant Biology, vol. 70, no. 1, pp. 667697. http://dx.doi.org/10.1146/annurev-arplant-050718-100049. PMid:30835493.

CHEN, Y.-J., LIU, P., NIELSEN, A.A., BROPHY, J.A., CLANCY, K., PETERSON, T. and VOIGT, C.A., 2013. Characterization of 582 natural and synthetic terminators and quantification of their design constraints. Nature Methods, vol. 10, no. 7, pp. 659-664. http://dx.doi.org/10.1038/nmeth.2515. PMid:23727987.

CHUNG, P.J., JUNG, H., JEONG, D.H., HA, S.H., CHOI, Y.D. and KIM, J.K., 2016. Transcriptome profiling of drought responsive noncoding RNAs and their target genes in rice. BMC Genomics, vol. 17, no. 1, pp. 563. http://dx.doi.org/10.1186/s12864-0162997-3. PMid:27501838.

CORTLEVEN, A., LEUENDORF, J.E., FRANK, M., PEZZETTA, D., BOLT, S. and SCHMÜLLING, T., 2019. Cytokinin action in response to abiotic and biotic stresses in plants. Plant, Cell \& Environment, vol. 42, no. 3, pp. 998-1018. http://dx.doi.org/10.1111/pce.13494. PMid:30488464.

CSORBA, T., QUESTA, J.I., SUN, Q. and DEAN, C., 2014. Antisense COOLAIR mediates the coordinated switching of chromatin states at FLC during vernalization. Proceedings of the National Academy of Sciences of the United States of America, vol. 111, no. 45, pp. 16160-16165. http://dx.doi.org/10.1073/pnas.1419030111. PMid:25349421.

CURABA, J., SINGH, M.B. and BHALLA, P.L., 2014. miRNAs in the crosstalk between phytohormone signalling pathways. Journal of Experimental Botany, vol. 65, no. 6, pp. 1425-1438. http:// dx.doi.org/10.1093/jxb/eru002. PMid:24523503.

CZARNECKA, E., VERNER, F.L. and GURLEY, W.B., 2012. A strategy for building an amplified transcriptional switch to detect bacterial contamination of plants. Plant Molecular Biology, vol. 78, no. 1-2, pp. 59-75. http://dx.doi.org/10.1007/s11103-011-9845-2. PMid:22116654.

DAI, S., KAI, W., LIANG, B., WANG, J., JIANG, L., DU, Y., SUN, Y. and LENG, P., 2018. The functional analysis of SINCED1 in tomato pollen development. Cellular and Molecular Life Sciences, vol. 75, no. 18, pp. 3457-3472. http://dx.doi.org/10.1007/s00018018-2809-9. PMid:29632966.

DEEBA, F., SULTANA, T., JAVAID, B., MAHMOOD, T. and NAQVI, S.M.S., 2017. Molecular characterization of a MYB protein from Oryza 
sativa for its role in abiotic stress tolerance. Brazilian Archives of Biology and Technology, vol. 60, no. 0, pp. 60. http://dx.doi. org/10.1590/1678-4324-2017160352.

DEGIFE, A.W., ZABEL, F. and MAUSER, W., 2021. Climate change impacts on potential maize yields in Gambella region, Ethiopia. Regional Environmental Change, vol. 21, no. 2, pp. 1-12. http:// dx.doi.org/10.1007/s10113-021-01773-3.

DEPAOLI, H.C., BORLAND, A.M., TUSKAN, G.A., CUSHMAN, J.C. and YANG, X., 2014. Synthetic biology as it relates to CAM photosynthesis: challenges and opportunities. Journal of Experimental Botany, vol. 65, no. 13, pp. 3381-3393. http:// dx.doi.org/10.1093/jxb/eru038. PMid:24567493.

DEVIREDDY, A.R., ZANDALINAS, S.I., FICHMAN, Y. and MITTLER, R., 2021. Integration of reactive oxygen species and hormone signaling during abiotic stress. The Plant Journal, vol. 105, no. 2 , pp. 459-476. http://dx.doi.org/10.1111/tpj.15010. PMid:33015917.

DING, Y., MA, Y., LIU, N., XU, J., HU, Q., LI, Y., WU, Y., XIE, S., ZHU, L., MIN, L. and ZHANG, X., 2017. micro RNA s involved in auxin signalling modulate male sterility under high temperature stress in cotton (Gossypium hirsutum). The Plant Journal, vol. 91, no. 6, pp. 977-994. http://dx.doi.org/10.1111/tpj.13620. PMid:28635129.

DJANAGUIRAMAN, M., PERUMAL, R., CIAMPITTI, I.A., GUPTA, S.K. and PRASAD, P.V.V., 2018. Quantifying pearl millet response to high temperature stress: thresholds, sensitive stages, genetic variability and relative sensitivity of pollen and pistil. Plant, Cell E Environment, vol. 41, no. 5, pp. 993-1007. http://dx.doi. org/10.1111/pce.12931. PMid:28173611.

DOWEN, R.H., PELIZZOLA, M., SCHMITZ, R.J., LISTER, R., DOWEN, J.M., NERY, J.R., DIXON, J.E. and ECKER, J.R., 2012. Widespread dynamic DNA methylation in response to biotic stress. Proceedings of the National Academy of Sciences of the United States of America, vol. 109, no. 32, pp. E2183-E2191. http://dx.doi.org/10.1073/ pnas.1209329109. PMid:22733782.

DUPUY, L., MACKENZIE, J., RUDGE, T. and HASELOFF, J., 2008. A system for modelling cell-cell interactions during plant morphogenesis. Annals of Botany, vol. 101, no. 8, pp. 12551265. http://dx.doi.org/10.1093/aob/mcm235. PMid:17921524.

DVORAK, P., KRASYLENKO, Y., ZEINER, A., SAMAJ, J. and TAKAC, T., 2020. Signaling toward ROS-scavenging enzymes in plants. Frontiers in Plant Science, vol. 11, pp. 2178.

FANG, X., TURNER, N.C., YAN, G., LI, F. and SIDDIQUE, K.H., 2010. Flower numbers, pod production, pollen viability, and pistil function are reduced and flower and pod abortion increased in chickpea (Cicer arietinum L.) under terminal drought. Journal of Experimental Botany, vol. 61, no. 2, pp. 335-345. http://dx.doi. org/10.1093/jxb/erp307. PMid:19854801.

FENG, B., ZHANG, C., CHEN, T., ZHANG, X., TAO, L. and FU, G., 2018. Salicylic acid reverses pollen abortion of rice caused by heat stress. BMC Plant Biology, vol. 18, no. 1, pp. 245. http://dx.doi. org/10.1186/s12870-018-1472-5. PMid:30340520.

FERGUSON, J.N., TIDY, A.C., MURCHIE, E.H. and WILSON, Z.A., 2021. The potential of resilient carbon dynamics for stabilizing crop reproductive development and productivity during heat stress. Plant, Cell \& Environment, vol. 44, no. 7, pp. 2066-2089. http:// dx.doi.org/10.1111/pce.14015. PMid:33538010.

FOYER, C.H., LAM, H.-M., NGUYEN, H.T., SIDDIQUE, K.H., VARSHNEY, R.K., COLMER, T.D., COWLING, W., BRAMLEY, H., MORI, T.A., HODGSON, J.M., COOPER, J.W., MILLER, A.J., KUNERT, K., VORSTER, J., CULLIS, C., OZGA, J.A., WAHLQVIST, M.L., LIANG, Y., SHOU, H., SHI, K., YU, J., FODOR, N., KAISER, B.N., WONG, F.L., VALLIYODAN, B. and CONSIDINE, M.J., 2016. Neglecting legumes has compromised human health and sustainable food production. Nature Plants, vol. 2, no. 8, pp. 16112. http://dx.doi. org/10.1038/nplants.2016.112. PMid:28221372.

FULEKY, G., 2009. Cultivated plants, primarily as food sources. Oxford: Eolss Publishers Company Limited, vol. 1.

GONZALO, M.J., LI, Y.-C., CHEN, K.-Y., GIL, D., MONTORO, T., NÁJERA, I., BAIXAULI, C., GRANELL, A. and MONFORTE, A.J., 2020. Genetic control of reproductive traits in tomatoes under high temperature. Frontiers in Plant Science, vol. 11, pp. 326. http:// dx.doi.org/10.3389/fpls.2020.00326. PMid:32391023.

GROTE, U., 2014. Can we improve global food security? A socioeconomic and political perspective. Food Security, vol. 6, no. 2, pp. 187-200. http://dx.doi.org/10.1007/s12571-013-0321-5.

GROVER, A., TWELL, D. and SCHLEIFF, E., 2016. Pollen as a target of environmental changes. Berlin: Springer. http://dx.doi. org/10.1007/s00497-016-0285-7.

GUIHUR, A., FAUVET, B., FINKA, A., QUADRONI, M. and GOLOUBINOFF, P., 2021. Quantitative proteomic analysis to capture the role of heat accumulated proteins in moss plant acquired thermotolerance. Plant, Cell \& Environment, vol. 44, no. 7, pp. 2117-2133. http://dx.doi.org/10.1111/pce.13975. PMid:33314263.

GUO, X.L., YUAN, S.N., ZHANG, H.N., ZHANG, Y.Y., ZHANG, Y.J., WANG, G.Y., LI, Y.Q. and LI, G.L., 2020. Heat-response patterns of the heat shock transcription factor family in advanced development stages of wheat (Triticum aestivum L.) and thermotolerance-regulation by TaHsfA2-10. BMC Plant Biology, vol. 20, no. 1, pp. 364. http://dx.doi.org/10.1186/s12870-02002555-5. PMid:32746866.

GUPTA, S., MISHRA, V.K., KUMARI, S., RAAVI., CHAND, R. and VARADWAJ, P.K., 2019. Deciphering genome-wide WRKY gene family of Triticum aestivum $\mathrm{L}$. and their functional role in response to Abiotic stress. Genes \& Genomics, vol. 41, no. 1, pp. 79-94. http://dx.doi.org/10.1007/s13258-018-0742-9. PMid:30238225.

HE, M., HE, C.-Q. and DING, N.-Z., 2018. Abiotic stresses: general defenses of land plants and chances for engineering multistress tolerance. Frontiers in Plant Science, vol. 9, pp. 1771. http://dx.doi. org/10.3389/fpls.2018.01771. PMid:30581446.

HEGLAND, S.J., NIELSEN, A., LÁZARO, A., BJERKNES, A.-L. and TOTLAND, Ø., 2009. How does climate warming affect plantpollinator interactions? Ecology Letters, vol. 12, no. 2, pp. 184-195. http://dx.doi.org/10.1111/j.1461-0248.2008.01269.x. PMid:19049509.

HEIN, N.T., CIAMPITTI, I.A. and JAGADISH, S.V.K., 2021. Bottlenecks and opportunities in field-based high-throughput phenotyping for heat and drought stress. Journal of Experimental Botany, vol. 72, no. 14, pp. 5102-5116. http://dx.doi.org/10.1093/jxb/ erab021. PMid:33474563.

HOLUBOVÁ, K., HENSEL, G., VOJTA, P., TARKOWSKI, P., BERGOUGNOUX, V. and GALUSZKA, P., 2018. Modification of barley plant productivity through regulation of cytokinin content by reversegenetics approaches. Frontiers in Plant Science, vol. 9, pp. 1676. http://dx.doi.org/10.3389/fpls.2018.01676. PMid:30542354.

HUNTER, M.C., SMITH, R.G., SCHIPANSKI, M.E., ATWOOD, L.W. and MORTENSEN, D.A., 2017. Agriculture in 2050: recalibrating targets for sustainable intensification. Bioscience, vol. 67, no. 4, pp. 386-391. http://dx.doi.org/10.1093/biosci/bix010.

HUSSAIN, H.A., MEN, S., HUSSAIN, S., ASHRAF, U., ZHANG, Q., ANJUM, S.A., ALI, I. and WANGET, L., 2019. Individual and concurrent effects of drought and chilling stresses on morpho-physiological characteristics and oxidative metabolism of maize cultivars. bioRxiv. In press.

IIZUMI, T., SAKUMA, H., YOKOZAWA, M., LUO, J.-J., CHALLINOR, A.J., BROWN, M.E., SAKURAI, G. and YAMAGATA, T., 2013. 
Prediction of seasonal climate-induced variations in global food production. Nature Climate Change, vol. 3, no. 10, pp. 904-908. http://dx.doi.org/10.1038/nclimate1945.

IMPA, S.M., RAJU, B., HEIN, N.T., SANDHU, J., PRASAD, P.V.V., WALIA, H. and JAGADISH, S.V.K., 2021. High night temperature effects on wheat and rice: current status and way forward. Plant, Cell E Environment, vol. 44, no. 7, pp. 2049-2065. http://dx.doi. org/10.1111/pce.14028. PMid:33576033.

INTERGOVERNMENTAL PANEL ON CLIMATE CHANGE - IPCC. (2013). The physical science basis, the Working Group I contribution to the IPCC fifth assessment report, summary for policy makers. Geneva: IPCC.

JAGADISH, S.V., 2020. Heat stress during flowering in cerealseffects and adaptation strategies. The New Phytologist, vol. 226, no. 6, pp. 1567-1572. http://dx.doi.org/10.1111/nph.16429. PMid:31943230.

JAGADISH, S.V., WAY, D.A. and SHARKEY, T.D., 2021. Plant heat stress: concepts directing future research. Plant, Cell \& Environment, vol. 44, no. 7, pp. 1992-2005. http://dx.doi.org/10.1111/pce.14050. PMid:33745205.

JAHAN, M.S., WANG, Y., SHU, S., ZHONG, M., CHEN, Z., WU, J., SUN, J. and GUO, S., 2019. Exogenous salicylic acid increases the heat tolerance in Tomato (Solanum lycopersicum L) by enhancing photosynthesis efficiency and improving antioxidant defense system through scavenging of reactive oxygen species. Scientia Horticulturae, vol. 247, pp. 421-429. http://dx.doi.org/10.1016/j. scienta.2018.12.047.

JHA, U.C., NAYYAR, H., JHA, R., KHURSHID, M., ZHOU, M., MANTRI, N. and SIDDIQUE, K.H.M., 2020. Long non-coding RNAs: emerging players regulating plant abiotic stress response and adaptation. BMC Plant Biology, vol. 20, no. 1, pp. 466. http:// dx.doi.org/10.1186/s12870-020-02595-x. PMid:33046001.

KASSAW, T.K., DONAYRE-TORRES, A.J., ANTUNES, M.S., MOREY, K.J. and MEDFORD, J.I., 2018. Engineering synthetic regulatory circuits in plants. Plant Science, vol. 273, pp. 13-22. http://dx.doi. org/10.1016/j.plantsci.2018.04.005. PMid:29907304.

KIM, W., IIZUMI, T. and NISHIMORI, M., 2019. Global patterns of crop production losses associated with droughts from 1983 to 2009. Journal of Applied Meteorology and Climatology, vol. 58, no. 6, pp. 1233-1244. http://dx.doi.org/10.1175/JAMC-D-18-0174.1.

KING, A.D., DONAT, M.G., FISCHER, E.M., HAWKINS, E., ALEXANDER, L.V., KAROLY, D.J., DITTUS, A.J., LEWIS, S.C. and PERKINS, S.E., 2015. The timing of anthropogenic emergence in simulated climate extremes. Environmental Research Letters, vol. 10, no. 9 , pp. 094015. http://dx.doi.org/10.1088/1748-9326/10/9/094015.

KOVALEVA, L.V., VORONKOV, A.S., ZAKHAROVA, E.V. and ANDREEV, I.M., 2018. ABA and IAA control microsporogenesis in Petunia hybrida L. Protoplasma, vol. 255, no. 3, pp. 751-759. http://dx.doi. org/10.1007/s00709-017-1185-x. PMid:29134282.

KUANG, J., LIU, J., MEI, J., WANG, C., HU, H., ZHANG, Y., SUN, M., NING, X., XIAO, L. and YANG, L., 2017. A class II small heat shock protein OsHsp18. 0 plays positive roles in both biotic and abiotic defense responses in rice. Scientific Reports, vol. 7, no. 1, pp. 11333. http://dx.doi.org/10.1038/s41598-017-11882-x. PMid:28900229.

KUMAR, P., YADAV, S. and SINGH, M.P., 2020. Bioregulators application improved heat tolerance and yield in chickpea (Cicer arietinum L.) by modulating zeaxanthin cycle. Plant Physiology Reports, vol. 25, no. 4, pp. 677-688. http://dx.doi.org/10.1007/ s40502-020-00555-z.

KUMAR, R.R., GOSWAMI, S., SHAMIM, M., MISHRA, U., JAIN, M., SINGH, K., SINGH, J.P., DUBEY, K., SINGH, S., RAI, G.K., SINGH, G.P., PATHAK, H., CHINNUSAMY, V. and PRAVEEN, S., 2017a.
Biochemical defense response: characterizing the plasticity of source and sink in spring wheat under terminal heat stress. Frontiers in Plant Science, vol. 8, pp. 1603. http://dx.doi. org/10.3389/fpls.2017.01603. PMid:28979274.

KUMAR, V., KHARE, T., SHARMA, M. and WANI, S.H. (2017b). ROSinduced signaling and gene expression in crops under salinity stress. In: M. KHAN and N. KHAN, eds. Reactive oxygen species and antioxidant systems in plants: role and regulation under abiotic stress. Singapore: Springer, pp. 159-184.

LE MOUËL, C. and FORSLUND, A., 2017. How can we feed the world in 2050? A review of the responses from global scenario studies. European Review of Agriculture Economics, vol. 44, no. 4, pp. 541-591. http://dx.doi.org/10.1093/erae/jbx006.

LEE, H.G. and SEO, P.J., 2019. MYB96 recruits the HDA15 protein to suppress negative regulators of ABA signaling in Arabidopsis. Nature Communications, vol. 10, no. 1, pp. 1713. http://dx.doi. org/10.1038/s41467-019-09417-1. PMid:30979883.

LEE, H.J., HORE, T.A. and REIK, W., 2014. Reprogramming the methylome: erasing memory and creating diversity. Cell Stem Cell, vol. 14, no. 6, pp. 710-719. http://dx.doi.org/10.1016/j. stem.2014.05.008. PMid:24905162.

LESK, C., ROWHANI, P. and RAMANKUTTY, N., 2016. Influence of extreme weather disasters on global crop production. Nature, vol. 529, no. 7584, pp. 84-87. http://dx.doi.org/10.1038/ nature16467. PMid:26738594.

LI, P., PENG, Z., XU, P., TANG, G., MA, C., ZHU, J., SHAN, L. and WAN, S., 2021. Genome-wide identification of NAC transcription factors and their functional prediction of abiotic stress response in peanut. Frontiers in Genetics, vol. 12, pp. 630292. http://dx.doi. org/10.3389/fgene.2021.630292. PMid:33767732.

LI, R., LIU, C., ZHAO, R., WANG, L., CHEN, L., YU, W., ZHANG, S., SHENG, J. and SHEN, L., 2019. CRISPR/Cas9-Mediated SINPR1 mutagenesis reduces tomato plant drought tolerance. BMC Plant Biology, vol. 19, no. 1, pp. 38. http://dx.doi.org/10.1186/ s12870-018-1627-4. PMid:30669982.

LIU, B., ASSENG, S., LIU, L., TANG, L., CAO, W. and ZHU, Y., 2016a. Testing the responses of four wheat crop models to heat stress at anthesis and grain filling. Global Change Biology, vol. 22, no. 5, pp. 1890-1903. http://dx.doi.org/10.1111/gcb.13212. PMid:26725507.

LIU, B., ASSENG, S., MÜLLER, C., EWERT, F., ELLIOTT, J., LOBELL, D.B., MARTRE, P., RUANE, A.C., WALLACH, D., JONES, J.W., ROSENZWEIG, C., AGGARWAL, P.K., ALDERMAN, P.D., ANOTHAI, J., BASSO, B., BIERNATH, C., CAMMARANO, D., CHALLINOR, A., DERYNG, D., SANCTIS, G.D., DOLTRA, J., FERERES, E., FOLBERTH, C., GARCIA-VILA, M., GAYLER, S., HOOGENBOOM, G., HUNT, L.A., IZAURRALDE, R.C., JABLOUN, M., JONES, C.D., KERSEBAUM, K.C., KIMBALL, B.A., KOEHLER, A.-K., KUMAR, S.N., NENDEL, C., O'LEARY, G.J., OLESEN, J.E., OTTMAN, M.J., PALOSUO, T., PRASAD, P.V.V., PRIESACK, E., PUGH, T.A.M., REYNOLDS, M., REZAEI, E.E., RÖTTER, R.P., SCHMID, E., SEMENOV, M.A., SHCHERBAK, I., STEHFEST, E., STÖCKLE, C.O., STRATONOVITCH, P., STRECK, T., SUPIT, I., TAO, F., THORBURN, P., WAHA, K., WALL, G.W., WANG, E., WHITE, J.W., WOLF, J., ZHAO, Z. and ZHU, Y., 2016b. Similar estimates of temperature impacts on global wheat yield by three independent methods. Nature Climate Change, vol. 6, no. 12, pp. 1130-1136. http://dx.doi.org/10.1038/nclimate3115.

LIU, D., MEWALAL, R., HU, R., TUSKAN, G.A. and YANG, X., 2017a. New technologies accelerate the exploration of non-coding RNAs in horticultural plants. Horticulture Research, vol. 4, no. 1, pp. 17031. http://dx.doi.org/10.1038/hortres.2017.31. PMid:28698797.

LIU, Q., YANG, T., YU, T., ZHANG, S., MAO, X., ZHAO, J., WANG, X., DONG, J. and LIU, B., 2017b. Integrating small RNA sequencing 
with QTL mapping for identification of miRNAs and their target genes associated with heat tolerance at the flowering stage in rice. Frontiers in Plant Science, vol. 8, pp. 43. http://dx.doi. org/10.3389/fpls.2017.00043. PMid:28174587.

LIU, X., WANG, X., WANG, X., GAO, J., LUO, N., MENG, Q. and WANG, P., 2020. Dissecting the critical stage in the response of maize kernel set to individual and combined drought and heat stress around flowering. Environmental and Experimental Botany, vol. 179, pp. 104213. http://dx.doi.org/10.1016/j.envexpbot.2020.104213.

LIU, Y., LI, J., ZHU, Y., JONES, A., ROSE, R.J. and SONG, Y., 2019. Heat stress in legume seed setting: effects, causes, and future prospects. Frontiers in Plant Science, vol. 10, pp. 938. http:// dx.doi.org/10.3389/fpls.2019.00938. PMid:31417579.

LLORENTE, B., WILLIAMS, T.C. and GOOLD, H.D., 2018. The multiplanetary future of plant synthetic biology. Genes, vol. 9, no. 7, pp. 348. http://dx.doi.org/10.3390/genes9070348. PMid:29996548.

LOBELL, D.B., ROBERTS, M.J., SCHLENKER, W., BRAUN, N., LITTLE, B.B., REJESUS, R.M. and HAMMER, G.L., 2014. Greater sensitivity to drought accompanies maize yield increase in the US Midwest. Science, vol. 344, no. 6183, pp. 516-519. http://dx.doi.org/10.1126/ science.1251423. PMid:24786079.

LOHANI, N., SINGH, M.B. and BHALLA, P., 2020a. RNA-seq highlights molecular events associated with impaired pollen-pistil interactions following short-term heat stress in Brassica napus. Frontiers in Plant Science, vol. 11, pp. 2150. PMid:33584763.

LOHANI, N., SINGH, M.B. and BHALLA, P.L., 2020b. High temperature susceptibility of sexual reproduction in crop plants. Journal of Experimental Botany, vol. 71, no. 2, pp. 555-568. http://dx.doi. org/10.1093/jxb/erz426. PMid:31560053.

LÓPEZ-GALIANO, M.J., GARCÍA-ROBLES, I., GONZÁLEZ-HERNÁNDEZ, A.I., CAMAÑES, G., VICEDO, B., REAL, M.D. and RAUSELL, C., 2019. Expression of miR159 is altered in tomato plants undergoing drought stress. Plants, vol. 8, no. 7, pp. 201. http://dx.doi. org/10.3390/plants8070201. PMid:31269704.

LOU, D., WANG, H., LIANG, G. and YU, D., 2017. OsSAPK2 confers abscisic acid sensitivity and tolerance to drought stress in rice. Frontiers in Plant Science, vol. 8, pp. 993. http://dx.doi. org/10.3389/fpls.2017.00993. PMid:28659944.

LUO, M., CHENG, K., XU, Y., YANG, S. and WU, K., 2017. Plant responses to abiotic stress regulated by histone deacetylases. Frontiers in Plant Science, vol. 8, pp. 2147. http://dx.doi.org/10.3389/ fpls.2017.02147. PMid:29326743.

MASOOMI-ALADIZGEH, F., NAJEEB, U., HAMZELOU, S., PASCOVICI, D., AMIRKHANI, A., TAN, D.K.Y., MIRZAEI, M., HAYNES, P.A. and ATWELL, B.J., 2021. Pollen development in cotton (Gossypium hirsutum) is highly sensitive to heat exposure during the tetrad stage. Plant, Cell \& Environment, vol. 44, no. 7, pp. 2150-2166. PMid:33047317.

MASSON-DELMOTTE, V., ZHAI, P., PÖRTNER, H.-O., ROBERTS, D., SKEA, J., SHUKLA, P.R., PIRANI, A., MOUFOUMA-OKIA, W., PÉAN, C., PIDCOCK, R., CONNORS, S., MATTHEWS, J.B.R., CHEN, Y., ZHOU, X., GOMIS, M.I., LONNOY, E., MAYCOCK, T., TIGNOR, M. and WATERFIELD, T., 2018. Global warming of 1.5 C: an IPCC special report on the impacts of global warming of $1.5^{\circ} \mathrm{C}$ above pre-industrial levels and related global greenhouse gas emission pathways, in the context of strengthening the global response to the threat of climate change, sustainable development, and efforts to eradicate poverty. Geneva: Intergovernmental Panel on Climate Change.

MAYER, K.S., CHEN, X., SANDERS, D., CHEN, J., JIANG, J., NGUYEN, P., SCALF, M., SMITH, L.M. and ZHONG, X., 2019. HDA9-PWR-HOS15 is a core histone deacetylase complex regulating transcription and development. Plant Physiology, vol. 180, no. 1, pp. 342-355. http://dx.doi.org/10.1104/pp.18.01156. PMid:30765479.

MEDINA, E., KIM, S.-H., YUN, M. and CHOI, W.-G., 2021. Recapitulation of the function and role of ROS generated in response to heat stress in plants. Plants, vol. 10, no. 2, pp. 371. http://dx.doi. org/10.3390/plants10020371. PMid:33671904.

MEMMOTT, J., CRAZE, P.G., WASER, N.M. and PRICE, M.V., 2007. Global warming and the disruption of plant-pollinator interactions. Ecology Letters, vol. 10, no. 8, pp. 710-717. http:// dx.doi.org/10.1111/j.1461-0248.2007.01061.x. PMid:17594426.

MICKELBART, M.V., HASEGAWA, P.M. and BAILEY-SERRES, J., 2015. Genetic mechanisms of abiotic stress tolerance that translate to crop yield stability. Nature Reviews. Genetics, vol. 16, no. 4, pp. 237-251. http://dx.doi.org/10.1038/nrg3901. PMid:25752530.

MING, M., REN, Q., PAN, C., HE, Y., ZHANG, Y., LIU, S., ZHONG, Z., WANG, J., MALZAHN, A.A., WU, J., ZHENG, X., ZHANG, Y. and QI, Y., 2020. CRISPR-Cas12b enables efficient plant genome engineering. Nature Plants, vol. 6, no. 3, pp. 202-208. http:// dx.doi.org/10.1038/s41477-020-0614-6. PMid:32170285.

MORADPOUR, M. and ABDULAH, S.N.A., 2020. CRISPR/dC as9 platforms in plants: strategies and applications beyond genome editing. Plant Biotechnology Journal, vol. 18, no. 1, pp. 32-44. http://dx.doi.org/10.1111/pbi.13232. PMid:31392820.

MOREY, K.J., ANTUNES, M.S., BARROW, M.J., SOLORZANO, F.A., HAVENS, K.L., SMITH, J.J. and MEDFORD, J., 2012. Crosstalk between endogenous and synthetic components-synthetic signaling meets endogenous components. Biotechnology Journal, vol. 7, no. 7, pp. 846-855. http://dx.doi.org/10.1002/ biot.201100487. PMid:22649041.

MULLINEAUX, P.M. and BAKER, N.R., 2010. Oxidative stress: antagonistic signaling for acclimation or cell death? Plant Physiology, vol. 154, no. 2, pp. 521-525. http://dx.doi.org/10.1104/ pp.110.161406. PMid:20921177.

NI, Z., LIU, N., YU, Y., BI, C., CHEN, Q. and QU, Y., 2021. The cotton $70-\mathrm{kDa}$ heat shock protein GhHSP70-26 plays a positive role in the drought stress response. Environmental and Experimental Botany, vol. 191, pp. 104628. http://dx.doi.org/10.1016/j. envexpbot.2021.104628.

NIELSEN, A.A., DER, B.S., SHIN, J., VAIDYANATHAN, P., PARALANOV, V., STRYCHALSKI, E.A., ROSS, D., DENSMORE, D. and VOIGT, C.A., 2016. Genetic circuit design automation. Science, vol. 352, no. 6281, pp. aac7341. http://dx.doi.org/10.1126/science.aac7341. PMid:27034378.

OHAMA, N., SATO, H., SHINOZAKI, K. and YAMAGUCHI-SHINOZAKI, K., 2017. Transcriptional regulatory network of plant heat stress response. Trends in Plant Science, vol. 22, no. 1, pp. 53-65. http:// dx.doi.org/10.1016/j.tplants.2016.08.015. PMid:27666516.

ORTIZ, R., SAYRE, K.D., GOVAERTS, B., GUPTA, R., SUBBARAO, G.V., BAN, T., HODSON, D., DIXON, J.M., IVÁN ORTIZ-MONASTERIO, J. and REYNOLDS, M., 2008. Climate change: can wheat beat the heat? Agriculture, Ecosystems \& Environment, vol. 126, no. 1-2, pp. 46-58. http://dx.doi.org/10.1016/j.agee.2008.01.019.

OSENI, T.O. and MASARIRAMBI, M.T., 2011. Effect of climate change on maize (Zea mays) production and food security in Swaziland. American-Eurasian Journal of Agricultural \& Environmental Sciences, vol. 11, no. 3, pp. 385-391.

PACHAURI, R.K. and MEYER, L.A., 2014. Climate change 2014: synthesis report. Contribution of working groups I, II and III to the fifth assessment report of the Intergovernmental Panel on Climate Change. Geneva: Intergovernmental Panel on Climate Change.

PACHAURI, R.K., ALLEN, M.R., BARROS, V.R., BROOME, J., CRAMER, W., CHRIST, R. and DASGUPTA, P., 2014. Climate change 2014: synthesis report. Contribution of Working Groups I, II and III to 
the fifth assessment report of the Intergovernmental Panel on Climate Change: IPCC. Geneva: IPCC.

PALAZZO, A.F. and KOONIN, E.V., 2020. Functional long noncoding RNAs evolve from junk transcripts. Cell, vol. 183, no. 5, pp. 1151-1161. http://dx.doi.org/10.1016/j.cell.2020.09.047. PMid:33068526.

PAN, C., YE, L., ZHENG, Y., WANG, Y., YANG, D., LIU, X., CHEN, L., ZHANG, Y., FEI, Z. and LU, G., 2017. Identification and expression profiling of microRNAs involved in the stigma exsertion under high-temperature stress in tomato. BMC Genomics, vol. 18, no. 1, pp. 843. http://dx.doi.org/10.1186/s12864-017-4238-9. PMid:29096602.

PANG, J., ZHANG, X., MA, X. and ZHAO, J., 2019. Spatio-temporal transcriptional dynamics of maize long non-coding RNAs responsive to drought stress. Genes, vol. 10, no. 2, pp. 138. http://dx.doi.org/10.3390/genes10020138. PMid:30781862.

PARK, H.J., BAEK, D., CHA, J.-Y., LIAO, X., KANG, S.-H., MCCLUNG, C.R., LEE, S.Y., YUN, D.J. and KIM, W.Y., 2019. HOS15 interacts with the histone deacetylase HDA9 and the evening complex to epigenetically regulate the floral activator GIGANTEA. The Plant Cell, vol. 31, no. 1, pp. 37-51. http://dx.doi.org/10.1105/ tpc.18.00721. PMid:30606777.

PARMESAN, C. and YOHE, G., 2003. A globally coherent fingerprint of climate change impacts across natural systems. Nature, vol. 421, no. 6918, pp. 37-42. http://dx.doi.org/10.1038/nature01286. PMid:12511946.

PAVLŮ, J., NOVÁK, J., KOUKALOVÁ, V., LUKLOVÁ, M., BRZOBOHATÝ, B. and ČERNÝ, M., 2018. Cytokinin at the crossroads of abiotic stress signalling pathways. International Journal of Molecular Sciences, vol. 19, no. 8, pp. 2450. http://dx.doi.org/10.3390/ ijms19082450. PMid:30126242.

PEGLER, J.L., OULTRAM, J.M.J., GROF, C.P.L. and EAMENS, A.L., 2019. Profiling the abiotic stress responsive microRNA landscape of Arabidopsis thaliana. Plants, vol. 8, no. 3, pp. 58. http://dx.doi. org/10.3390/plants8030058. PMid:30857364.

POIDEVIN, L., FORMENT, J., UNAL, D. and FERRANDO, A., 2020. Transcriptome and translatome changes in germinated pollen under heat stress uncover roles of transporter genes involved in pollen tube growth. Plant, Cell \& Environment, vol. 44, no. 7, pp. 2167-2184. PMid:33289138.

POTTS, S.G., IMPERATRIZ-FONSECA, V., NGO, H.T., AIZEN, M.A., BIESMEIJER, J.C., BREEZE, T.D., DICKS, L.V., GARIBALDI, L.A., HILL, R., SETTELE, J. and VANBERGEN, A.J., 2016a. Safeguarding pollinators and their values to human well-being. Nature, vol. 540, no. 7632, pp. 220-229. http://dx.doi.org/10.1038/ nature20588. PMid:27894123.

POTTS, S.G., IMPERATRIZ-FONSECA, V., NGO, H.T., HIEN, T., BIESMEIJER, J.C., BREEZE, T.D., DICKS, L.V. and VANBERGEN, A.J. (2016b). Summary for policymakers of the assessment report of the Intergovernmental Science-Policy Platform on Biodiversity and Ecosystem Services on pollinators, pollination and food production. Bonn: Intergovernmental Science-Policy Platform on Biodiversity and Ecosystem Services.

PRAMANIK, D., SHELAKE, R.M., KIM, M.J. and KIM, J.-Y., 2020. CRISPR-mediated engineering across the central dogma in plant biology for basic research and crop improvement. Molecular Plant, vol. 14, no. 1, pp. 127-150. PMid:33152519.

RAI, M.I., ALAM, M., LIGHTFOOT, D.A., GURHA, P. and AFZAL, A.J., 2019. Classification and experimental identification of plant long non-coding RNAs. Genomics, vol. 111, no. 5, pp. 997-1005. http://dx.doi.org/10.1016/j.ygeno.2018.04.014. PMid:29679643.

RAMADAN, M., ALARIQI, M., MA, Y., LI, Y., LIU, Z., ZHANG, R., JIN, S. MIN, L. and ZHANG, X., 2021. Efficient CRISPR/Cas9 mediated
Pooled-sgRNAs assembly accelerates targeting multiple genes related to male sterility in cotton. Plant Methods, vol. 17, no. 1, pp. 1-13. http://dx.doi.org/10.1186/s13007-021-00712-x. PMid:33557889.

RAMIREDDY, E., HOSSEINI, S.A., EGGERT, K., GILLANDT, S., GNAD, H., VON WIRÉN, N. and SCHMÜLLING, T., 2018. Root engineering in barley: increasing cytokinin degradation produces a larger root system, mineral enrichment in the shoot and improved drought tolerance. Plant Physiology, vol. 177, no. 3, pp. 10781095. http://dx.doi.org/10.1104/pp.18.00199. PMid:29871980.

RASUL, G., 2021. Twin challenges of COVID-19 pandemic and climate change for agriculture and food security in South Asia. Environmental Challenges, vol. 2, pp. 100027. http://dx.doi. org/10.1016/j.envc.2021.100027.

RAZA, A., RAZZAQ A., MEHMOOD, S.S., ZOU, X., ZHANG, X., LV, Y. and XU, J., 2019. Impact of climate change on crops adaptation and strategies to tackle its outcome: a review. Plants, vol. 8, no. 2, pp. 34. http://dx.doi.org/10.3390/plants8020034. PMid:30704089.

RAZA, A., TABASSUM, J., KUDAPA, H. and VARSHNEY, R.K., 2021. Can omics deliver temperature resilient ready-to-grow crops? Critical Reviews in Biotechnology, vol. 41, no. 8, pp. 1209. http:// dx.doi.org/10.1080/07388551.2021.1898332. PMid:33827346.

REN, S., MA, K., LU, Z., CHEN, G., CUI, J., TONG, P., WANG, L., TENG, N. and JIN, B., 2019. Transcriptomic and metabolomic analysis of the heat-stress response of populus tomentosa carr. Forests, vol. 10, no. 5, pp. 383. http://dx.doi.org/10.3390/f10050383.

REZAUL, I.M., BAOHUA, F., TINGTING, C., WEIMENG, F., CAIXIA, Z., LONGXING, T. and GUANFU, F., 2019. Abscisic acid prevents pollen abortion under high-temperature stress by mediating sugar metabolism in rice spikelets. Physiologia Plantarum, vol. 165, no. 3, pp. 644-663. http://dx.doi.org/10.1111/ppl.12759. PMid:29766507.

RUSHTON, P.J., BOKOWIEC, M.T., LAUDEMAN, T.W., BRANNOCK, J.F., CHEN, X. and TIMKO, M.P., 2008. TOBFAC: the database of tobacco transcription factors. BMC Bioinformatics, vol. 9, no. 1, pp. 53. http://dx.doi.org/10.1186/1471-2105-9-53. PMid:18221524.

RUSTAD, L.E., 2008. The response of terrestrial ecosystems to global climate change: towards an integrated approach. The Science of the Total Environment, vol. 404, no. 2-3, pp. 222-235. http:// dx.doi.org/10.1016/j.scitotenv.2008.04.050. PMid:18675444.

SANTIAGO, J.P., SOLTANI, A., BRESSON, M.M., PREISER, A.L., LOWRY, D.B. and SHARKEY, T.D., 2021. Contrasting anther glucose-6phosphate dehydrogenase activities between two bean varieties suggest an important role in reproductive heat tolerance. Plant, Cell E'Environment, vol. 44, no. 7, pp. 2185-2199. http://dx.doi. org/10.1111/pce.14057. PMid:33783858.

SARASWAT, S., YADAV, A.K., SIROHI, P. and SINGH, N.K., 2017. Role of epigenetics in crop improvement: water and heat stress. Journal of Plant Biology, vol. 60, no. 3, pp. 231-240. http://dx.doi. org/10.1007/s12374-017-0053-8.

SEDEEK, K., MAHAS, A. and MAHFOUZ, M., 2019. Plant genome engineering for targeted improvement of crop traits. Frontiers in Plant Science, vol. 10, pp. 114. http://dx.doi.org/10.3389/ fpls.2019.00114. PMid:30809237.

SERRANO, N., LING, Y., BAHIELDIN, A. and MAHFOUZ, M.M., 2019. Thermopriming reprograms metabolic homeostasis to confer heat tolerance. Scientific Reports, vol. 9, no. 1, pp. 181. http:// dx.doi.org/10.1038/s41598-018-36484-z. PMid:30655560.

SHI, J., GAO, H., WANG, H., LAFITTE, H.R., ARCHIBALD, R.L., YANG, M., HAKIMI, S.M., MO, H. and HABBEN, J.E., 2017. ARGOS 8 variants generated by CRISPR-Cas9 improve maize grain yield under field drought stress conditions. Plant Biotechnology 
Journal, vol. 15, no. 2, pp. 207-216. http://dx.doi.org/10.1111/ pbi.12603. PMid:27442592.

SHIFERAW, B., SMALE, M., BRAUN, H.-J., DUVEILLER, E., REYNOLDS, M. and MURICHO, G., 2013. Crops that feed the world 10. Past successes and future challenges to the role played by wheat in global food security. Food Security, vol. 5, no. 3, pp. 291-317. http://dx.doi.org/10.1007/s12571-013-0263-y.

SMITH, M.R., SINGH, G.M., MOZAFFARIAN, D. and MYERS, S.S., 2015. Effects of decreases of animal pollinators on human nutrition and global health: a modelling analysis. Lancet, vol. 386, no. 10007, pp. 1964-1972. http://dx.doi.org/10.1016/ S0140-6736(15)61085-6. PMid:26188748.

SONG, A., ZHU, X., CHEN, F., GAO, H., JIANG, J. and CHEN, S., 2014. A chrysanthemum heat shock protein confers tolerance to abiotic stress. International Journal of Molecular Sciences, vol. 15, no. 3, pp. 5063-5078. http://dx.doi.org/10.3390/ijms15035063. PMid:24663057.

SONG, X., HU, J., WU, T., YANG, Q., FENG, X., LIN, H., FENG, S., CUI, C., YU, Y., ZHOU, R., GONG, K., YU, T., PEI, Q. and LI, N., 2021. Comparative analysis of long noncoding RNAs in angiosperms and characterization of long noncoding RNAs in response to heat stress in Chinese cabbage. Horticulture Research, vol. 8 , no. 1, pp. 48. http://dx.doi.org/10.1038/s41438-021-00484-4. PMid:33642591.

STRATONOVITCH, P. and SEMENOV, M.A., 2015. Heat tolerance around flowering in wheat identified as a key trait for increased yield potential in Europe under climate change. Journal of Experimental Botany, vol. 66, no. 12, pp. 3599-3609. http:// dx.doi.org/10.1093/jxb/erv070. PMid:25750425.

SUN, X., LIN, L. and SUI, N., 2019. Regulation mechanism of microRNA in plant response to abiotic stress and breeding. Molecular Biology Reports, vol. 46, no. 1, pp. 1447-1457. http://dx.doi. org/10.1007/s11033-018-4511-2. PMid:30465132.

SUZUKI, N., BASSIL, E., HAMILTON, J.S., INUPAKUTIKA, M.A., ZANDALINAS, S.I., TRIPATHY, D., LUO, Y., DION, E., FUKUI, G., KUMAZAKI, A., NAKANO, R., RIVERO, R.M., VERBECK, G.F., AZAD, R.K., BLUMWALD, E. and MITTLER, R., 2016. ABA is required for plant acclimation to a combination of salt and heat stress. PLoS One, vol. 11, no. 1, pp. e0147625. http://dx.doi.org/10.1371/ journal.pone.0147625. PMid:26824246.

TACK, J., BARKLEY, A. and NALLEY, L.L., 2015. Effect of warming temperatures on US wheat yields. Proceedings of the National Academy of Sciences of the United States of America, vol. 112, no. 22, pp. 6931-6936. http://dx.doi.org/10.1073/pnas.1415181112. PMid:25964323.

TADESSE, W., BISHAW, Z. and ASSEFA, S., 2019. Wheat production and breeding in Sub-Saharan Africa. International Journal of Climate Change Strategies and Management, vol. 11, no. 5, pp. 696-715. http://dx.doi.org/10.1108/IJCCSM-02-2018-0015.

TSANIKLIDIS, G., PAPPI, P., TSAFOUROS, A., CHAROVA, S.N., NIKOLOUDAKIS, N., ROUSSOS, P.A., PASCHALIDIS, K.A. and DELIS, C., 2020. Polyamine homeostasis in tomato biotic/abiotic stress cross-tolerance. Gene, vol. 727, pp. 144230. http://dx.doi. org/10.1016/j.gene.2019.144230. PMid:31743771.

VALLIYODAN, B., YE, H., SONG, L., MURPHY, M., SHANNON, J.G. and NGUYEN, H.T., 2017. Genetic diversity and genomic strategies for improving drought and waterlogging tolerance in soybeans. Journal of Experimental Botany, vol. 68, no. 8, pp. 1835-1849. PMid:27927997.

VARSHNEY, R.K., SINGH, V.K., HICKEY, J.M., XUN, X., MARSHALL, D.F., WANG, J., EDWARDS, D. and RIBAUT, J.M., 2016. Analytical and decision support tools for genomics-assisted breeding.
Trends in Plant Science, vol. 21, no. 4, pp. 354-363. http://dx.doi. org/10.1016/j.tplants.2015.10.018. PMid:26651919.

VEILLET, F., DURAND, M., KROJ, T., CESARI, S. and GALLOIS, J.L., 2020. Precision breeding made real with CRISPR: illustration through genetic resistance to pathogens. Plant Communications, vol. 1, no. 5, pp. 100102. http://dx.doi.org/10.1016/j.xplc.2020.100102. PMid:33367260.

WANG, L., CHEN, L., LI, R., ZHAO, R., YANG, M., SHENG, J. and SHEN, L., 2017. Reduced drought tolerance by CRISPR/Cas9-mediated SIMAPK3 mutagenesis in tomato plants. Journal of Agricultural and Food Chemistry, vol. 65, no. 39, pp. 8674-8682. http://dx.doi. org/10.1021/acs.jafc.7b02745. PMid:28873302.

WANG, X., FAN, J., XING, Y., XU, G., WANG, H., DENG, J., WANG, Y., ZHANG, F., LI, P. and LI, Z., 2019. The effects of mulch and nitrogen fertilizer on the soil environment of crop plants. Advances in Agronomy, vol. 153, pp. 121-173. http://dx.doi. org/10.1016/bs.agron.2018.08.003.

WANG, X., WANG, G., GUO, T., XING, Y., MO, F., WANG, H., FAN, J. and ZHANG, F., 2021a. Effects of plastic mulch and nitrogen fertilizer on the soil microbial community, enzymatic activity and yield performance in a dryland maize cropping system. European Journal of Soil Science, vol. 72, no. 1, pp. 400-412. http://dx.doi.org/10.1111/ejss.12954.

WANG, Y.I., IMPA, S.M., SUNKAR, R. and JAGADISH, S.V.K., 2021 b. The neglected other half-role of the pistil in plant heat stress responses. Plant, Cell E Environment, vol. 44, no. 7, pp. 22002210. http://dx.doi.org/10.1111/pce.14067. PMid:33866576.

WANG, Z., WANG, Y., KOHALMI, S.E., AMYOT, L. and HANNOUFA, A., 2016. Squamosa promoter binding protein-like 2 controls floral organ development and plant fertility by activating asymmetric leaves 2 in Arabidopsis thaliana. Plant Molecular Biology, vol. 92, no. 6, pp. 661-674. http://dx.doi.org/10.1007/ s11103-016-0536-x. PMid:27605094.

WEI, T., CHERRY, T.L., GLOMRøD, S. and ZHANG, T., 2014. Climate change impacts on crop yield: evidence from China. The Science of the Total Environment, vol. 499, pp. 133-140. http://dx.doi. org/10.1016/j.scitotenv.2014.08.035. PMid:25181045.

WEIDONG, Q.I., HONGPING, C.H.E.N., ZUOZHEN, Y.A.N.G., BIAOLIN, H.U., XIANGDONG, L., BING, A., YUAN, L., YU, H., JIANKUN, X. and FANTAO, Z., 2020. Systematic characterization of long noncoding RNAs and their responses to drought stress in Dongxiang wild rice. Rice Science, vol. 27, no. 1, pp. 21-31. http://dx.doi. org/10.1016/j.rsci.2019.12.003.

WIERZBICKI, A.T., BLEVINS, T. and SWIEZEWSKI, S., 2021. Long noncoding RNAs in plants. Annual Review of Plant Biology, vol. 72, no. 1, pp. 245. http://dx.doi.org/10.1146/annurevarplant-093020-035446. PMid:33752440.

WORLD HEALTH ORGANIZATION - WHO, 2019. The state of food security and nutrition in the world 2019: safeguarding against economic slowdowns and downturns. Geneva: WHO, vol. 2019.

XIANG, X.-Y., CHEN, J., XU, W.-X., QIU, J.-R., SONG, L., WANG, J.-T., TANG, R., CHEN, D., JIANG, C.Z. and HUANG, Z., 2021. Dehydration-Induced WRKY transcriptional factor MfWRKY70 of Myrothamnus flabellifolia enhanced drought and salinity tolerance in arabidopsis. Biomolecules, vol. 11, no. 2, pp. 327. http://dx.doi.org/10.3390/biom11020327. PMid:33671480.

XIN, M., WANG, Y., YAO, Y., SONG, N., HU, Z., QIN, D., XIE, C., PENG, H., NI, Z. and SUN, Q., 2011. Identification and characterization of wheat long non-protein coding RNAs responsive to powdery mildew infection and heat stress by using microarray analysis and SBS sequencing. BMC Plant Biology, vol. 11, no. 1, pp. 61. http://dx.doi.org/10.1186/1471-2229-11-61. PMid:21473757. 
XING, S., SALINAS, M., HÖHMANN, S., BERNDTGEN, R. and HUIJSER, P., 2010. miR156-targeted and nontargeted SBP-box transcription factors act in concert to secure male fertility in Arabidopsis. The Plant Cell, vol. 22, no. 12, pp. 3935-3950. http://dx.doi. org/10.1105/tpc.110.079343. PMid:21177480.

ZAHID, K.R., ALI, F., SHAH, F., YOUNAS, M., SHAH, T., SHAHWAR, D. HASSAN, W., AHMAD, Z., QI, C., LU, Y., IQBAL, A. and WU, W., 2016. Response and tolerance mechanism of cotton Gossypium hirsutum L. to elevated temperature stress: a review. Frontiers in Plant Science, vol. 7, pp. 937. http://dx.doi.org/10.3389/ fpls.2016.00937. PMid:27446165.

ZANDALINAS, S.I., MITTLER, R., BALFAGÓN, D., ARBONA, V. and GÓMEZ-CADENAS, A., 2018. Plant adaptations to the combination of drought and high temperatures. Physiologia Plantarum, vol. 162, no. 1, pp. 2-12. http://dx.doi.org/10.1111/ppl.12540. PMid:28042678.

ZHANG, B., 2015. MicroRNA: a new target for improving plant tolerance to abiotic stress. Journal of Experimental Botany, vol. 66, no. 7, pp. 1749-1761. http://dx.doi.org/10.1093/jxb/erv013. PMid:25697792.

ZHANG, C., LI, G., CHEN, T., FENG, B., FU, W., YAN, J., ISLAM, M.R., JIN, Q., TAO, L. and FU, G., 2018. Heat stress induces spikelet sterility in rice at anthesis through inhibition of pollen tube elongation interfering with auxin homeostasis in pollinated pistils. Rice, vol. 11, no. 1, pp. 14. http://dx.doi.org/10.1186/ s12284-018-0206-5. PMid:29532187.

ZHANG, W., HAN, Z., GUO, Q., LIU, Y., ZHENG, Y., WU, F. and JIN, W., 2014. Identification of maize long non-coding RNAs responsive to drought stress. PLoS One, vol. 9, no. 6, e98958. http://dx.doi. org/10.1371/journal.pone.0098958. PMid:24892290.

ZHANG, Y., MALZAHN, A.A., SRETENOVIC, S. and QI, Y., 2019a. The emerging and uncultivated potential of CRISPR technology in plant science. Nature Plants, vol. 5, no. 8, pp. 778-794. http:// dx.doi.org/10.1038/s41477-019-0461-5. PMid:31308503.

ZHANG, Z., TEOTIA, S., TANG, J. and TANG, G., 2019b. Perspectives on microRNAs and phased small interfering RNAs in maize (Zea mays L.): functions and big impact on agronomic traits enhancement. Plants, vol. 8, no. 6, pp. 170. http://dx.doi. org/10.3390/plants8060170. PMid:31212808.

ZHAO, J., HE, Q., CHEN, G., WANG, L. and JIN, B., 2016. Regulation of non-coding RNAs in heat stress responses of plants. Frontiers in Plant Science, vol. 7, pp. 1213. http://dx.doi.org/10.3389/ fpls.2016.01213. PMid:27588021.

ZHAO, C., LIU, B., PIAO, S., WANG, X., LOBELL, D.B., HUANG, Y., HUANG, M., YAO, Y., BASSU, S., CIAIS, P., DURAND, J.L., ELLIOTT, J., EWERT, F., JANSSENS, I.A., LI, T., LIN, E., LIU, Q., MARTRE, P., MÜLLER, C., PENG, S., PEÑUELAS, J., RUANE, A.C., WALLACH, D., WANG, T., WU, D., LIU, Z., ZHU, Y., ZHU, Z. and ASSENG, S., 2017a. Temperature increase reduces global yields of major crops in four independent estimates. Proceedings of the National Academy of Sciences of the United States of America, vol. 114, no. 35, pp. 9326-9331. http://dx.doi.org/10.1073/pnas.1701762114. PMid:28811375

ZHAO, Y., TIAN, X., WANG, F., ZHANG, L., XIN, M., HU, Z., YAO, Y., NI, Z., SUN, Q. and PENG, H., 2017b. Characterization of wheat MYB genes responsive to high temperatures. BMC Plant Biology, vol. 17, no. 1, pp. 208. http://dx.doi.org/10.1186/s12870-0171158-4. PMid:29157199.

ZHAO, B., LIU, Q., WANG, B. and YUAN, F., 2021a. Roles of phytohormones and their signaling pathways in leaf development and stress responses. Journal of Agricultural and Food Chemistry, vol. 69, no. 12, pp. 3566-3584. http://dx.doi. org/10.1021/acs.jafc.0c07908. PMid:33739096.

ZHAO, J., LU, Z., WANG, L. and JIN, B., 2021b. Plant responses to heat stress: physiology, transcription, noncoding RNAs, and epigenetics. International Journal of Molecular Sciences, vol. 22, no. 1, pp. 117. http://dx.doi.org/10.3390/ijms22010117. PMid:33374376.

ZISKA, L.H., PETTIS, J.S., EDWARDS, J., HANCOCK, J.E., TOMECEK, M.B., CLARK, A., DUKES, J.S., LOLADZE, I. and POLLEY, H.W., 2016. Rising atmospheric $\mathrm{CO}_{2}$ is reducing the protein concentration of a floral pollen source essential for North American bees. Proceedings of the Royal Society B: Biological Sciences, vol. 283, no. 1828, pp. 20160414. http://dx.doi.org/10.1098/rspb.2016.0414. 